INR 69[1] EVANS: Page 1 of 57

Nicholas Evans

\title{
Irish chronicles as sources for the history of northern Britain, A.D. 660
}

$800^{1}$

The Irish chronicles, along with sources from England, especially the Anglo-Saxon Chronicle and

Bede's 'Ecclesiastical History of the English People', provide the chronological framework that underpins the narrative history of northern Britain in the seventh and eighth centuries. ${ }^{2}$ Other texts help to illuminate various aspects of the period's societies, but their limitations in chronological and geographical coverage, and subject-matter, as well as difficulties in determining their early contents, mean that historical texts with chronologies form the basis for reconstructing the narrative skeleton of this period. An understanding of these chronological texts as sources is therefore crucial not only for their own interpretation but also for the study of many other witnesses.

\footnotetext{
${ }^{1}$ I would like to thank Dauvit Broun, who supervised the postgraduate work from which this has evolved, the many people who have read and commented on drafts of this article or conference and seminar papers on this subject, and in particular David Dumville, Paul Russell, and the anonymous referee, for their contributions to improving drafts of this text.

${ }^{2}$ The Anglo-Saxon Chronicle. A Collaborative Edition, gen. edd. David Dumville and S. Keynes, III, MS. A, ed. Janet M. Bately (Cambridge, 1986); IV, MS. B, ed. Simon Taylor (Cambridge, 1983); v, MS. C, ed. Katherine O'Brien O'Keeffe (Cambridge, 2001); VI, MS. D, ed. G. P. Cubbin (Cambridge, 1996). Bede's Ecclesiastical History of the English People, ed. and trans. Bertram Colgrave and R. A. B. Mynors (Oxford, 1969; rev. imp., 1991); Symeon of Durham, Historia Regum Anglorum, Part I, ed. Thomas Arnold, Symeonis Monachi Opera Omnia, 2 vols (London, 1882/5), II, 3-98; Continuatio Bedae, in Venerabilis Baedae Opera Historica, ed. Charles Plummer, 2 vols (Oxford, 1896), I, 361-3 (notes at II, 345-7). For discussion of the last two texts, proposing respectively Pictish and Gaelic sources for a few entries in them, see Katherine Forsyth and John T. Koch, 'Evidence of a lost Pictish source in the Historia regum Anglorum of Symeon of Durham', in Kings, Clerics and Chronicles in Scotland, 500-1297. Essays in Honour of Marjorie Ogilvie Anderson on the Occasion of her Ninetieth Birthday, ed. Simon Taylor (Dublin, 2000), 19-34. The terms 'the north of Britain' or 'northern Britain' will be used in this study to describe the geographical area controlled by Dál Riata, the Picts, the northern Britons of Dumbarton and the Northumbrians. The term "northern Britons' will be confined to the Brittonic-speaking people in what are now southern Scotland and northern England.
} 
The focus of this article will be those Irish chronicles which describe events in northern Britain from 660 to 800 . Several students of the period have studied the Irish chronicles' sources for northern Britain, but the result has been often contradictory interpretations. My intention here is to reconsider the theories already proposed and to provide new evidence about where and when individual events recorded in Irish chronicles were written down and how they have been transmitted to us.

Gaelic chronicles survive in manuscripts no earlier than the later eleventh century, and their interrelationships have rarely been firmly established. The exceptions are 'The Annals of Ulster' (AU), 'The Annals of Tigernach' (AT), and Chronicum Scotorum (CS). ${ }^{3}$ These texts will be the focus of this study. 'The Annals of Ulster' are found in two versions. Version A is in the late

\footnotetext{
${ }^{3}$ For a study of their inter-relationships, see Nicholas Evans, The Present and the Past in Medieval Irish Chronicles (Woodbridge, 2010), which fundamentally disagrees with Daniel P. McCarthy, The Irish Annals. Their Genesis, Evolution and History (Dublin, 2008). Dates given for AU will be those in The Annals of Ulster (to A.D. 1131), I, ed. and trans. Seán Mac Airt and Gearóid Mac Niocaill (Dublin, 1983). For AT and CS the dates will be those of the equivalent annal in AU, but in AT the annal will also be identified by the number of kalends in the text from the start of the third fragment up to AT kl 156, the annal equivalent to AU 656. For AT, Whitley Stokes's edition and translation of AT, 'The Annals of Tigernach', Revue celtique 16 (1895), 374-419; 17 (1896), 6-33, 119-263, 337-420; 18 (1897), 9-59, 150-98, 267-303, 390-1; (2nd edn, 2 vols, Felinfach, 1993), lacks dates and some of the kalends and ferials which introduce new annals in the manuscript; so see Henry Gough-Cooper for an edition of the third fragment covering ca. 488-766 with numeration at https://www.academia.edu/7440729/Annals of Tigernach the Third Fragment. From Oxford Bodleian_Library

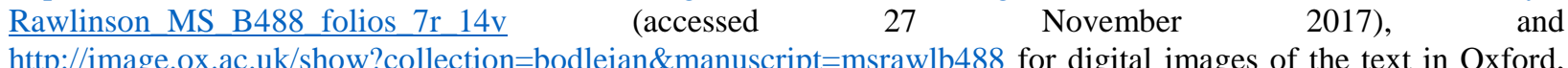
Bodleian Library, MS. Rawlinson B.488. The chronology of the relevant fragment of AT is different from AU up to AU 656, but after that AT neither lacks nor adds any annals by comparison with those in AU. To obtain the correct actual year, which before AU 711 is sometimes not the same as the AU date, and to see a full list of corresponding annals in AU, AT, and CS, see Evans, The Present, 235-43. For the section from 660 to 722 the dates for CS entries given here are corrected, being four years higher than in Chronicum Scotorum. A Chronicle of Irish Affairs, from the Earliest Times to A.D. 1135; with a Supplement, containing the Events from 1141 to 1150, ed. and trans. William M. Hennessy (London, 1866). After AU 656, AT and CS from will be given the year of the equivalent annal in AU, with the year placed in square brackets.

${ }^{4}$ I shall nevertheless refer to the other chronicles too: 'The Annals of Inisfallen' [AI], ed. and trans. Seán Mac Airt, The Annals of Inisfallen (MS. Rawlinson B. 503) (Dublin, 1951); 'Fragmentary Annals of Ireland' [FAI], ed. and trans. Joan Newton Radner, Fragmentary Annals of Ireland (Dublin, 1978); 'The Annals of Roscrea' [ARC], ed. D.F. Gleeson and S. Mac Airt, 'The Annals of Roscrea', Proceedings of the Royal Irish Academy 59 C (1957-9) 137-80, checked against Bart Jaski and Daniel Mc Carthy, A facsimile edition of the Annals of Roscrea, https://www.scss.tcd.ie/misc/kronos/editions/AR_portal.htm, accessed 24 April 2013; 'The Annals of Clonmacnoise' [AClon], ed. Denis Murphy, The Annals of Clonmacnoise being Annals of Ireland from the earliest period to A.D. 1408 (Dublin, 1896, repr. Felinfach, 1993); 'The Annals of Boyle' [AB], ed. A.M. Freeman, 'The Annals in Cotton MS Titus A xxv', Revue celtique 41 (1924), 301-30; 42 (1925), 283-305; 43 (1926), 358-84; 44 (1927), 336-61; and 'The Annals of the Four Masters' [AFM], ed. and trans. J. O’Donovan, Annála Ríoghachta Eireann: Annals of the
} 
fifteenth-century manuscript now Dublin, Trinity College, MS. 1282 (H.1.8); B is in an early sixteenth-century manuscript, Oxford, Bodleian Library, MS. Rawlinson B.489 (S.C. 11836), and may be an independent witness to an earlier common source. ${ }^{5}$ But the items for northern Britain in B are nevertheless largely identical to A, so B's variants will only be given where these are significant for the discussion. ${ }^{6}$ 'The Annals of Tigernach', in a fourteenth-century manuscript

Kingdom of Ireland, by the Four Masters, from the Earliest Period to the Year 1616, 2nd edn, 7 vols (Dublin, 1856); Mionannála, ed. and trans. Standish O'Grady, Silva Gadelica (I-XXI). A Collection of Tales in Irish with Extracts illustrating Irish Persons and Places, 2 vols (London, 1892), I (Gaelic text),390-415, II (English trans.), 424-49). These are all likely to contain many entries from the Clonmacnoise-group (Kathryn Grabowski and David Dumville, Chronicles and Annals of Mediaeval Ireland and Wales. The Clonmacnoise-group Texts (Woodbridge, 1984), 111, 166), but often they also have entries from other chronicles. They have not been studied in detail, so studies of these texts are required to identify their relationships to AU, AT, and CS and to determine the sources of individual entries. References to entries in AB, AClon, AFM, AI, ARC, and FAI will be included in this article, but they do not generally form part of the article's analysis. ARC entries will be marked with an asterisk for those which are additions later than the initial phase of the text's compilation, but I have excluded all those identified by Jaski and Mc Carthy as the additions of Thomas O'Sheerin from other sources (Mac Airt and Gleeson, 'The Annals of Roscrea', 143; Jaski and Mc Carthy, A facsimile, 10-17, 23). All ARC items are given an item number for identification purposes, although the layout (see ibid.) is more confusing than is apparent in the edition by Mac Airt and Gleeson.

${ }^{5}$ The Annals of Ulster, edd. and transl. Mac Airt and Mac Niocaill, viii-ix; Caoimhín Breatnach, 'The Annals of Ulster: verse, sources and editions', in Aon don éigse: essays marking Osborn Bergin's centenary lecture on bardic poetry (1912), ed. Caoimhín Breatnach and Meidhbhín Ní Úrdail (Dublin, 2015), 221-38.

${ }^{6}$ The B text of AU has all the entries for northern Britain found in A, with very few differences apart from orthographical variations. The most significant exceptions are (with references to the AU MS. A equivalent item): the obit of Tuathal son of Morgan (AU 663.4), which replaces mors with $e t$, therefore following AT [663].5, CS [663].5; Máel Rubae nauigauit rather than nauigat to Britain in AU 671.5 (differing also from AT [671].4 and CS [671].4); in its item on the Battle of Nechtansmere B has in quo after Saxonum, replacing the reign-length in AU 686.1 (AT [686].4); Adomnán duxit rather than reduxit captives to Ireland (AU 687.5, also differing from AT [687].6, CS [687].5); the B succession item for Fáelchú son of Dorbéne to the 'cathedra of Columba' (AU 716.5, AT [716].4) adds sue; as in AT [719].4, the B item on the battle of Finnglenn lacks the $u i$ in the date found interlinearly in A (AU 719.6), when uii is likely to have been the correct reading (The Chronicle of Ireland, trans. T. M. Charles-Edwards, 2 vols (Liverpool, 2006), I, 193, n. 2); as in AT [719].5, the item on the Battle of Ard Nesbi (AU 719.5) has the correct Octobris in B rather than A's Septimbris (with uel Octimbris interlinearly added in the H1 hand) (The Annals of Ulster, edd. and transl. Mac Airt and Mac Niocaill, 174-5); B adds sue after etatis in the obituary notice of Máel Rubae (sue is not in the A text 722.1 or AT [722].1); the B item on the Battle of Monid Carno (AU 729.3) has exactores rather than A's otherwise unattested exactatores (Alex Woolf, 'AU 729.2 and the last years of Nechtan mac Der-Ilei', The Scottish Historical Review, 85.1 (April, 2006), 131-4); the obit of Cummene nepos of Bécc in B lacks Ego (AU 752.2); the second item on the battle between Conall and Constantín (AU 790.7) is Uel hic bellum Conaill et Constantin secundum alios libros in B rather than A's Bellum Conaill et Custantin hic scriptum est in aliis libris; AU 794.7 has gentibus in B replacing A's gentilibus; AU 795.3 in B has scri, the same as the A text's original reading before it was later marked for deletion by the addition of a subscript point, which might support Downham's suggestion (Clare Downham, 'An Imaginary Viking-Raid on Skye in 795?', Scottish Gaelic Studies 20 [2000], 1926) that the text was not originally sci (the Isle of Skye), but scrin ('shrine'), since scri is likely to have been the reading of the common source of manuscripts A and B. The evidence of these items therefore supports Breatnach's suggestion than texts A and B of AU were not copies of each other, but were derived from a common source, since A and B each have their own mistakes and readings where the other manuscript of AU corresponds to the text of AT or CS. However, the question requires a more detailed study. 
(Oxford, Bodleian Library, MS. Rawlinson B.488 [S.C.11835]), and Chronicum Scotorum, written in the mid-seventeenth century by An Dubhaltach Mac Fhirbhisigh (Dublin, Trinity College, MS. 1292 [H.1.18]), ${ }^{7}$ are based on a common ancestor dated between $c .1110$ and the mid-fourteenth century. ${ }^{8}$ These two versions are categorised as part of the 'Clonmacnoise-group', so described because their common source was a derivative of 'The Chronicle of Clonmacnoise' kept and maintained at Clonmacnoise from the mid-eleventh century (at the latest) after a period starting no earlier than 911 when Clonmacnoise and probably Clonard were the chronicling centres. ${ }^{9} \mathrm{AU}$ covers all of A.D. 660 to 800, but CS is lacunose from part of the annal for 722 to 804 , and AT also becomes lacunose after recording three events for 766. The common ancestor of AT and CS itself shared a common source with AU for the annals before A.D. 912; this source is known as 'The Chronicle of Ireland'. ${ }^{10}$

For much of the twentieth century scholars have argued that a 'Chronicle of Iona' formed an important constituent part of the 'The Chronicle of Ireland', being the source for many, if not all, of the entries for northern Britain before about 740. Eoin Mac Neill in 1913 and T. F. O’Rahilly in 1946 suggested that an Ionan source was responsible for these entries, but it was John Bannerman who undertook the first detailed study of the issue in the 1960s. ${ }^{11}$ Bannerman argued that a contemporary chronicle kept at Iona from at least 685 produced the entries about northern Britain between A.D. 500 and 740. He pointed out evidence for an origin in northern Britain for a

\footnotetext{
${ }^{7}$ Nollaig Ó Muraíle, The Celebrated Antiquary Dubhaltach Mac Fhirbhisigh (c.1600-1671). His Lineage, Life and Learning, 2nd edn (Maynooth, 2002), 97-107.

${ }^{8}$ [Grabowski and] Dumville, Chronicles, 182-3.

${ }^{9}$ Ibid., p. 6; Evans, The Present, 45-90.

${ }^{10}$ Kathleen Hughes, Early Christian Ireland: Introduction to the Sources (London, 1972), 101, 107; Grabowski [and Dumville], Chronicles, 53-6; Evans, The Present, 67-72.

${ }^{11}$ E. Mac Neill, 'The authorship and structure of the "Annals of Tigernach", Ériu 7 (1913), 30-113, at 80; T. F. O'Rahilly, Early Irish History and Mythology (Dublin, 1946), 255; John Bannerman, 'Notes on the Scottish entries in the early Irish annals', Scottish Gaelic Studies 11 (1966-8), 149-70, republished in his Studies in the History of Dalriada (Edinburgh, 1974), 9-26.
} 
number of entries: the wording of some travel-entries indicates that they were written in northern Britain; many events in northern Britain are precisely dated; and an interest in forts, the taking of prisoners, drownings, and shipwrecks is apparent in the record of events in northern Britain, but not Ireland. The Irish chronicles also contain references to other people connected with Iona, a full record of abbots of Iona, and have ecclesiastical-succession entries only for Ionan clergymen, all of which factors indicate that these entries were derived from an Ionan source. Bannerman suggested that a movement of 'The Chronicle of Iona' to Ireland about this time explained both the lower number of entries concerned with northern Britain and the Irish perspective of travelentries after 740 .

Isabel Henderson, while agreeing with the idea of a 'Chronicle of Iona', proposed in the late 1960s and early 1970s that the account of the Pictish civil war of 728-9 (which perhaps began in 724) and entries on the Picts after 750 in Irish chronicles were derived from either a Pictish narrative or a Pictish chronicle or both. ${ }^{12}$ In addition, Henderson maintained that entries found only in AU from about 670 to about 750 displayed a more northerly interest than 'The Chronicle of Iona' and were probably written at Applecross (Ross and Cromarty), a monastery on the mainland opposite Skye, founded by Máel Rubai in $673 .{ }^{13}$

Kathleen Hughes agreed largely with John Bannerman's analysis in her book Early Christian Ireland: Introduction to the Sources (published in 1972); she stated that entries found only in either AU or AT could often have been derived from 'The Chronicle of Iona' ${ }^{14}$ She warned, however, that annal-final blocks of entries unique to one chronicle could be additions. Later, in her study of the Welsh Latin chronicle Annales Cambriae, Hughes suggested that a

\footnotetext{
${ }^{12}$ Isabel Henderson, The Picts (London, 1967), 167-8.

${ }^{13}$ I. Henderson, 'North Pictland', in The Dark Ages in the Highlands, ed. E. Meldrum (Inverness, 1971), 43-9.

${ }^{14}$ Hughes, Early Christian Ireland, 101, 103.
} 
'North-British chronicle', which contained an account of the conflict between the Britons and the English in the seventh century and various records as far as about 780, was also included in 'The Chronicle of Ireland'. ${ }^{15}$ Hughes also argued, from the high level of detail about the Picts in the chronicles from 724 to 741 , that a 'Pictish chronicle', perhaps maintained at St Andrews (Fife), was a source. ${ }^{16}$

In 1973 Marjorie Anderson included an analysis of the Irish chronicles in Kings and Kingship in Early Scotland, in which she supported Bannerman's theory of a 'Chronicle of Iona' and a movement of this chronicle to Ireland about $740 .{ }^{17}$ Anderson differed from Isabel Henderson because she considered relevant entries found only in AU to have been part of 'The Chronicle of Iona' but regarded entries surviving only in the Clonmacnoise-group as late additions from kinglists, a chronicle from a Columban monastery in Ireland, and other sources. ${ }^{18}$

Subsequent scholarship has generally supported Bannerman's theory of a 'Chronicle of Iona', the view that it began before 660 , and that a copy of the text went to Ireland $c .740 .{ }^{19}$ In 1981 A. A. M. Duncan argued that the Northumbrian Ecgberht played a role in the production of 'The Iona Chronicle', especially by including Pictish material, from about 713 to 729 while he was a monk of Iona. ${ }^{20}$ More recently, Thomas Charles-Edwards, while judging entries unique to AU or AT and CS on a case-by-case basis, tended towards accepting such items as original and from 'The Chronicle of Iona'. ${ }^{21}$ However, he noted the example of the battle duplicated in 789 and 790

\footnotetext{
${ }^{15}$ Kathleen Hughes, Celtic Britain in the Early Middle Ages (Woodbridge, 1980), 94-100.

${ }^{16}$ Ibid., 97-8.

${ }^{17}$ Marjorie O. Anderson, Kings and Kingship in Early Scotland (Edinburgh, 1973; 2nd edn, 1980; repr. 2011), 1-42, at $7-22,30-42$.

${ }^{18}$ Ibid., 32-8, 41-2.

${ }^{19}$ The Chronicle of Ireland, trans. Charles-Edwards, I, 7-9; Mc Carthy, The Irish Annals, 150-1, 164-7; Evans, The Present, 2, 171-3; Roy Flechner, 'The Chronicle of Ireland: then and now', Early Medieval Europe 21 (2013), 42254 , at 425.

${ }^{20}$ Archibald A. M. Duncan, 'Bede, Iona and the Picts', in The Writing of History in the Middle Ages. Essays presented to R.W. Southern, ed. R. H. C. Davis and J. M. Wallace-Hadrill (Oxford, 1981), 1-42, at 36.

${ }^{21}$ The Chronicle of Ireland, trans. Charles-Edwards, I, 15-20.
} 
involving Conall son of Tadg and Constantine as evidence that other sets of annals could have been used as a source, and suggested that the 'Iona Chronicle' was the result of the combining in the second half of the seventh century of two set of Columban annals, one starting soon after Columba's arrival at Iona, the other begun no later than $642 .{ }^{22}$

Daniel Mc Carthy, compared with preceding scholars, has a very different view of the overall development of the Irish chronicles and has proposed a series of changes made by Adomnán and Ecgberht, who advocated the adoption of the Dionysiac method of Easter reckoning in Iona and among the Picts. ${ }^{23}$ These alterations (the existence of which is very questionable) concern the chronological apparatus and the earlier sections of the chronicle, and so - apart from two parts of his argument - they do not concern the contemporary record of northern Britain in A.D. $660-800$ which is the focus here. One part of Mc Carthy's argument is that a later AT mirabilia addition to the 744 annal about a whale washing ashore in County Down was an allegory for the movement of 'The Iona Chronicle' to Ireland. The other is his view that Bede used 'The Iona Chronicle' for his De Temporibus (written A.D. 703) and his De Temporum Ratione (completed A.D. 725), which could mean that an item in the latter about Ecgberht and the Easter controversy on Iona was taken from the Irish annals. Neither hypothesis can be accepted. ${ }^{24}$

James E. Fraser has identified people from northern Britain in the Irish chronicles, and as a result has studied the scope and interests of 'The Iona Chronicle'. ${ }^{25}$ His monograph, From Caledonia to Pictland. Scotland to 793, generally follows pre-existing scholarship regarding the

\footnotetext{
${ }^{22}$ Ibid., 22, 38, 55-8.

${ }^{23}$ Mc Carthy, The Irish Annals, 133-67. For discussion of Mc Carthy's argument, see Evans, The Present, 115-70, especially 117-18, 123-4, 146-53, 169-70, and The Chronicle of Ireland, trans. Charles-Edwards, I, 35-58, especially 51, 57 (which contradicts Mc Carthy's conclusions).

${ }^{24}$ Ibid., 153, 163-7 (165-6, for the whale and its golden teeth). For a refutation of Mc Carthy's view on the relationship of Bede's texts and the Irish annals, see Evans, The Present, 119-20, 123-4.

${ }^{25}$ James E. Fraser, 'The Iona Chronicle, the Descendants of Áedan mac Gabráin, and the 'Principal Kindreds of Dál Riata', Northern Studies 38 (2004), 77-96, with the illustrations published in 'Addendum', Northern Studies 39 (2005), 125-30; James E. Fraser, From Caledonia to Pictland. Scotland to 795 (Edinburgh, 2009), 370-3.
} 
existence of 'The Chronicle of Iona', although he has suggested that it was created in multiple stages of compilation, the first $c$. 643, the second following $c$. 670, after which it was a contemporary chronicle to $c .741{ }^{26}$ Fraser has not mentioned the theory of an 'Applecross Chronicle', but has agreed with Hughes that a 'North British Chronicle' was a source for the Irish chronicles to $c .780$, and has supported Henderson and Hughes in suggesting the existence of Pictish sources for the account of the career of Unuist son of Uurguist from the late 720 s to the conquest of Dál Riata and for Pictish events after $740 .{ }^{27}$ Fraser has proposed that after $c .741$ 'The Iona Chronicle' continued, with less of a focus on Argyll's politics, but maybe more on the ecclesiastical centres of Lismore and Kingarth, with information being transferred from Iona possibly with a Columban establishment in Ireland as an intermediary. ${ }^{28}$

I have concentrated on wider issues of the relationships of AU, AT, and CS, and on patterns of omission and addition, particularly for kingship items, rather than on the sources of the material relating to northern Britain. ${ }^{29}$ The exceptions have been that I have argued for the view that some Dál Riata and Alba entries were added into the Clonmacnoise group after 911 from king-lists, and against Kathleen Hughes's theory of a 'North-British Chronicle' in the eighth century underlying entries in the Irish chronicles, although I have proposed that in the seventh century an initially British then Anglo-Saxon source could have provided records of events for Iona chroniclers. ${ }^{30} \mathrm{I}$ have also countered Duncan's argument about the importance of Ecgberht for the Irish chronicles

\footnotetext{
${ }^{26}$ Fraser, From Caledonia, 370-1. He also argued (ibid., 371) that during the reign of Bridei son of Bile (A.D. 67192) a Pictish king-list was used to include kings as far back as the Columba's lifetime.

${ }^{27}$ Ibid., 371-2. He suggests Dunkeld as a source after 740, citing connections with Armagh, and two obituary items for Dunkeld's abbots, but these occur in the second half of the ninth century (on them, see Dauvit Broun, 'Dunkeld and the Origin of Scottish Identity', in Spes Scotorum. Hope of Scots. St Columba, Iona and Scotland, ed. Dauvit Broun and T. O. Clancy [Edinburgh, 1999], 95-111, at 99-102).

${ }^{28}$ Fraser, From Caledonia, 371-3. Note that given the uncertainty about whether references to Lismore clerics (see ibid., 372, n. 73, for a list) relate to the centre in Ireland or Scotland, I have not included them in this analysis.

${ }^{29}$ Evans, The Present.

${ }^{30}$ Ibid., 208-13; Nicholas Evans, 'The Irish Chronicles and the British to Anglo-Saxon Transition in Seventh-century Northumbria', in The Medieval Chronicle VII, ed. Juliana Dresvina and Nicholas Sparks (Amsterdam, 2011), 15-38.
} 
and other sources from northern Britain. ${ }^{31}$ While I have accepted the theory of an 'Iona Chronicle', as with other historians, I have not discussed in detail the sources for most of the entries on northern Britain.

It is clear from this brief survey that scholars have generally agreed on the existence of a 'Chronicle of Iona' but have taken varying positions on the extent of the text and on the existence of other postulated sources either already present in 'The Chronicle of Ireland' or added later to 'The Annals of Ulster' or the Clonmacnoise-group. Current scholarship tends to favour an Iona source for all entries from northern Britain to $c$. 740, but without the issue being considered in depth. But that does not mean further progress is not possible.

In particular, analysis of the vocabulary and phraseology of entries to determine their sources, an approach not attempted to any great extent hitherto, could yield significant results. ${ }^{32}$ One implication of the formulaic nature of the Irish chronicle-record is that lexical choice, phrasestructure, and content can be typical of one particular chronicle or chronicler. It is unlikely that two chronicles would share the same combination of stylistic features or use vocabulary in the same way; therefore entries sharing stylistic features of limited geographical or chronological range were probably written at one and the same centre. The result of combining this and other textual approaches to the Irish chronicles is that it becomes clear that most entries describing events in northern Britain from 660 to 740 were derived from 'The Chronicle of Iona' (as John Bannerman suggested but did not prove). ${ }^{33}$ This text was itself most likely reliant in part on local, probably written, sources of information, because areas of northern Britain have entries with stylistic features not found elsewhere, as well as details which could indicate that notices were being written

\footnotetext{
${ }^{31}$ Nicholas Evans, 'The Calculation of Columba's Arrival in Britain in Bede's 'Ecclesiastical History' and the Pictish King-lists', Scottish Historical Review 87 (2008), 183-205.

32 See Evans, The Present, 17-44, for a similar analysis of AU 912-1100.

${ }^{33}$ Bannerman, Studies, 10, 14-15, 18.
} 
down locally. ${ }^{34}$ Furthermore, the received view that 'The Chronicle of Iona' ceased to be a source for the Irish chronicles after 740 can be challenged, because the evidence, though greatly reduced, indicates that the situation is more complex than has previously been supposed, with a number of sources, perhaps including a 'Chronicle of Iona', continuing to provide written notices of events for Irish chroniclers.

Entries shared by $A U$ and the Clonmacnoise-group

In the period from 660 to 800 there are entries shared by $\mathrm{AU}$ and the Clonmacnoise-group which contain details of confined interest indicative of centres of chronicling. Five entries for Ionan churchmen, two of which include exact dates, are the only ecclesiastical-succession entries during this period:

AU 707.9 (AT [707].5): Dúnchad principatum Iae tenuit.

AU 713.5 (AT [713].5): ${ }^{35}$ Dorbéni kathedram Iae obtenuit et .v. mensibus peractis in primatu, .v. kl. Nouimbris die Sabbati obiit.

AU 716.5 (AT [716].4): ${ }^{36}$ Faelchú mac Dorbéni kathedram Columbae .lxxiiii. aetatis anno in .iiii. kl. Septimbris suscepit.

AU 722.6 (AT [722].8): ${ }^{37}$ Feidilmid principatum Iae tenuit.

AU 724.1 (AT [724].1): ${ }^{38}$ Faelchú m. Dorbéni, abbas Iae, dormiuit. Cillenius longus ei in principatum Iae successit.

\footnotetext{
${ }^{34}$ See below, pp. \$\$ \$ \$ $(13,22-3)$

${ }^{35}$ ARC $\$ 168.5$, AFM 713.2.

${ }^{36}$ ARC $\$ 169.1$, AClon 713.2, AFM 714.6.

${ }^{37}$ ARC $\$ * 173.2$.

${ }^{38}$ FAI $§ 185$, AFM 720.2 .
} 
Two more ecclesiastical entries - one about the drowning of members of the Ionan community and the other about the death of Máel Rubai of Applecross - include exact dates, but these only occur in either AU or a Clonmacnoise-group text.

AU 691.5: Uentus magnus .x.vi. kl. Octimbris quosdam .vi. ex familia Iae mersit.

AT [722].1 (AU 722.1): ${ }^{39}$ Maelruba, in Apurchrooson ando .lxxx. etaitis tribus mensibus et .xix. diebus peractis, in .xi. kl. Maias tercie ferie die, pausat.

Apart from the obit of Máel Rubai, these seven entries display a strong interest in Iona, which makes it likely that they were written there. The AT-version of Máel Rubai's obit, which gives his age and a precise date for his death, could have been written in Applecross, but it shares two words, peractis and pausat, which are found elsewhere in relation to Iona ecclesiastics. ${ }^{40}$ There are few other entries on Applecross and Máel Rubai: the sailing of Máel Rubai to Britain (AU 671.5, AT [671].4, CS [671].4), ${ }^{41}$ the foundation of Applecross (AU 673.5, AT [673].4, CS [673].3), ${ }^{42}$ and the drowning of Máel Rubai's successor, Faílbe mac Guaire, along with twenty-two sailors (AU 737.1, AT [737].2). ${ }^{43}$ These demonstrate a degree of interest in Applecross, but it is striking that there are no entries about Applecross for nearly fifty years, from 674 to 721 . Given Máel Rubai’s lengthy abbacy, an Ionan chronicler is likely to have been sufficiently interested to include these

\footnotetext{
${ }^{39}$ ARC §*173.1, AFM 721.2. AU 722.1 has only Mael rubai i nApur Chroson anno .lxxx. etatis.

${ }^{40}$ Peractis is also found in AU 713.5, AT [713].5. Pausat or the perfective form pausauit are found sixteen times in both AU and the Clonmacnoise-group 660×740. Four of these (AU 692.1, AT [692].1, CS [692]; AU 704.2, AT [704].3; AU 710.1, AT [710].1; AU 712.1, AT [712].1) involve Ionan ecclesiastics, while Colmán (ob. AU 676.1, AT [676].1) was a former bishop of Lindisfarne, an offshoot of Iona. Pausat is also found in the obit for Ecgberht (AU 729.1), who played a role in convincing Iona to change its method of calculating Easter, but AT's entry for this event (AT [729].1) lacks this word, having its Gaelic equivalent (as a result of subsequent translation). For discussion of AT entries translated into Gaelic, see Anderson, Kings, 39-40, Evans, The Present, 52-4. It should be noted that pausat is also found five times with Clonmacnoise ecclesiastics before 741 .

${ }^{41}$ ARC $\$ 138.1$, AFM 671.2.

${ }^{42}$ ARC $\$ 140.1$, AFM 671.2.

${ }^{43}$ AClon 734.1, AFM 732.3.
} 
entries, writing such a detailed obit entry for him; therefore all these succession- and dated entries, including those about Applecross, were probably written at Iona. ${ }^{44}$

There are also four records of dated battles: Dún Nechtain (known in Old English as Nechtanesmere), between Picts and the Northumbrians (AU 686.1, AT [686].4); ${ }^{45}$ Finnglenn, between two sons of Ferchar Fota of Cenél Loairn (AU 719.6, AT [719].4); bellum maritimum Ardae Nesbi fought by Dál Riata (AU 719.7, AT [719].5); and the AT-version of bellum Dromo Derg Blathuug among the Picts (AT [729].4). ${ }^{46}$ In these cases it is likely that local information in Dál Riata and Pictland was available to the chroniclers, but the entries do not contain sufficient evidence to indicate where this information came from. ${ }^{47}$

The Irish chronicles contain travel-entries: most, if not all, describe journeys between Britain (Britannia) and Ireland (Hibernia). Bannerman has suggested that these entries were written from a viewpoint in northern Britain in the period before 740; but Anderson was more cautious, arguing that entries including AU 730.3 (AT [730].1), ${ }^{48}$ Reuersio reliquiarum Adomnani de Hibernia mense Octimbris ('The return of the relics of Adomnán from Ireland in the month of October'), could have been written from an Irish perspective. ${ }^{49}$ In Anderson's opinion, only AU 670.4 (AT [670].6 and CS [670].4) ${ }^{50}$, Uenit genus Garnaith de Hibernia ('The people of Gartnait came from Ireland'), can be proved from its wording to have been written in Britain, presumably

\footnotetext{
${ }^{44}$ The influence of Applecross may also have been a factor, but this is difficult to gauge. For the importance of Applecross as a centre for sculpture, see D. MacLean, 'Maelrubai, Applecross, and the late Pictish contribution west of Druimalban', in The Worm, the Germ and the Thorn. Pictish and Related Studies presented to Isabel Henderson, ed. David Henry (Balgavies 1997), 173-87.

${ }^{45}$ AI 685, FAI $\$ 96$.

${ }^{46}$ FAI §197, AClon 726.3. The battle of Druim Derg Blathuug is not precisely dated in AU [729].3; so it is uncertain whether the date was in the original version of the entry.

${ }^{47}$ Both the dated battles in 719 share the use of ferials to denote the day of the week and are proceeded by die, 'on the day', indications that they both came from the same source.

${ }^{48}$ ARC §181.1, AClon 727.1.

${ }^{49}$ Bannerman, Studies, 11-12; Anderson, Kings, 7-8, 11. Part of Anderson's argument was based on the similarly worded entry AT [758].2, which she considered to have been written in Ireland.

${ }^{50}$ ARC (left margin) $\S * 138$, AClon 666.1.
} 
because she interpreted uenit to mean 'comes' or 'came', indicating movement towards the writer. ${ }^{51}$ However, it is not certain that uenit always meant movement towards the writer; in Tírechán's Collectanea, written in the late-seventh century, uenit is frequently used in a more general sense when someone travelled to a place. ${ }^{52}$ When the travel-entries are thoroughly examined as a group, patterns emerge which indicate that most were indeed written from the perspective of someone in Britain.

The travel-entries can be divided into three groups: those which describe journeys from Britain to Ireland followed by a later entry describing the journey back from Ireland to Britain; voyages from Ireland to Britain; and journeys from Britain to Ireland.

Group 1. Travel-entries from Britain to Ireland and back

AU 668.3 (AT [668].1, CS [668].2): ${ }^{53}$. . et nauigatio filiorum Gartnaidh ad Hiberniam cum plebe Sceth.

AU 670.4 (AT [670].6, CS [670].4): $:{ }^{54}$ Uenit genus Garnaith de Hibernia.

AU 673.4 (AT [673].3, CS [673].2): ${ }^{.5}$ Nauigatio Faelbei abbatis Iae in Hiberniam.

AU 676.5 (AT [676].3, CS [676].4): ${ }^{56}$ Faelbe de Hibernia reuertitur.

AU 727.3 (AT [727].5): ${ }^{57}$ Adomnani reliquiae transferuntur in Hiberniam, et lex renouatur.

AU 730.3 (AT [730].1): ${ }^{.5}$ Reuersio reliquiarum Adomnani de Hibernia mense Octimbris.

\footnotetext{
${ }^{51}$ Anderson, Kings, 8 (n. 32), 11.

${ }^{52}$ For examples, see Tírechán, Collectanea, $\S 3,5,9,10$, ed. and trans. Ludwig Bieler, The Patrician Texts in the Book of Armagh (Dublin, 1979), 123-67, at 126, 132.

${ }^{53}$ ARC $\$ 136.1$.

${ }^{54}$ ARC (left margin) §138, AClon 666.1.

${ }^{55}$ ARC \$139.1, AClon 669.2, AFM 671.4.

${ }^{56}$ ARC $\S * 141.3$, AFM 674.5.

${ }^{57}$ ARC $\S * 177.3$ and $\$ 178.1$, FAI $\$ 199$.

${ }^{58}$ ARC $§ 181.1$, AClon 727.1.
} 
In cases where the journeys both from Britain to Ireland and back again are given, it is striking that Ireland, but not Britain, is mentioned in all the entries. When composing such entries a chronicler could have written ' $\mathrm{X}$ travelled from Britain to Ireland' and ' $\mathrm{X}$ travelled from Ireland to Britain', but, if either Britain or Ireland were obvious as the destination or point of departure, then one might expect that a chronicler would omit one or the other. From the viewpoint of someone there, Britain would be more obvious; therefore a British-based chronicler would probably write ' $\mathrm{X}$ travelled to Ireland' and ' $\mathrm{X}$ travelled from Ireland', whereas an Irish-based chronicler would probably mention Britain but not Ireland. Therefore, the fact that only Ireland is mentioned suggests that the chroniclers producing these entries were writing in Britain.

The prepositions employed in these entries also provide evidence supporting this conclusion. Anderson correctly pointed out that the use of de, 'from', and the words reuertitur ('returns', from the deponent verb reuerti) in AU 676.5 (AT [676].3, CS [676].4) and reuersio ('return') in AU 730.3 (AT [730].1) does not necessarily demonstrate that these entries were written in Britain. However, de is only found in relation to journeys from Ireland to Britain, while the previous notices of the journeys from Britain to Ireland have either ad ('to') or in ('into'), which seems to indicate that the writers of these entries did perceive the two journeys differently. The probable source of difference is the writers' geographical perspective, with de signifying a journey towards the author(s). ${ }^{59}$

\footnotetext{
${ }^{59}$ It could be argued that de merely signifies a return journey, used with the words reuersio and reuertitur. This argument depends somewhat on the assumption that the chroniclers knew that those undertaking the journeys would normally reside in Britain; otherwise there would be more of a sense in these entries that they were going from Ireland rather than returning to Britain. However, in all three cases the return-journey was two or three years after the outward journey; so those involved were clearly in Ireland for a few years. It is perhaps surprising, therefore, that none of the entries describes those involved as 'going to Britain'.
} 
The second group of travel entries comprises accounts of journeys from Ireland to Britain. Given the close cultural connections between Ireland and Dál Riata in this period, it is likely that many events in Ireland were recorded in 'The Chronicle of Iona', as Alfred Smyth has suggested. ${ }^{60}$ An implication of this is that entries describing journeys from Ireland to Britain could have been written in northern Britain.

Group 2. Travel-entries from Ireland to Britain

AU 671.5 (AT [671].4, CS [671].4): ${ }^{61}$ Mail Rubai in Britanniam nauigat.

AU 700.5 (AT [700].4): ${ }^{62}$ Aurthuile nepos Crunnmail, de regno expulsus, in Britanniam pergit.

AU 714.4 (AT [714].4, CS [714].2):63 Fógartach ua Cernaigh de regno expulsus est; in Brittaniam init.

In all these entries the destination, Britannia, is mentioned, but not Hibernia. As it would probably have been obvious to chroniclers writing in Britain that these persons came from Ireland, this increased the likelihood that Britannia would be mentioned; so it is probably mistaken to draw any inference of an Irish perspective from this. It is perhaps more significant that no entries survive which mention any return-journeys to Ireland by the people in these entries. Aurthuile ua Crunnmaíl may not have returned to Ireland after his expulsion, but Fógartach ua Cernaig did, because a subsequent entry, AU 716.3 (AT [716].2, CS [716].1), has Fóghartach nepos Cernaigh iterum regnat. It is also slightly surprising that there is no entry describing any return-journeys to

${ }^{60}$ Smyth, 'The earliest Irish Annals: their first contemporary Entries, and the earliest Centres of Recording', Proceedings of the Royal Irish Academy 72 C (1972), 1-48, at 35-43.

${ }^{61}$ ARC \$138.1, AFM 671.2.

${ }^{62}$ ARC $\$ * 158.4$, AFM 698.5.

${ }^{63}$ AFM 712.3. 
Ireland by Máel Rubai, especially if Applecross was founded as a daughter-house of Bangor, although it is a possibility that he never again visited Ireland after his voyage to Britain. ${ }^{64}$ It may be that return-journeys to Ireland were of less interest to the chroniclers than the initial journeys to Britain. This contrasts with the three entries already discussed concerning return-voyages from Ireland. The sum of the distribution may thus be held to indicate that these entries came from a source in Britain, although the evidence is not conclusive.

Group 3. Travel-entries from Britain to Ireland

AT [661].4 (CS [661].4): ${ }^{65}$ Cumíne abas ad Hiberniam uenit.

AU 668.3 (AT [668].1, CS [668].1):66 Nauigatio Columbani episcopi <cum> reliquis sanctorum ad Insolam Uaccae Albae, in qua fundauit aeclesiam . . ${ }^{67}$

AU 687.5 (AT [687].5, CS [687].5): ${ }^{68}$ Adomnanus captiuos reduxit ad Hiberniam .lx.

AU 692.1 (AT [692].1, CS [692].1): ${ }^{69}$ Adomnanus .xiiii ${ }^{o}$. anno post pausam Failbhei ad Hiberniam pergit.

AU 697.3 (AT [697].3, CS [697].1): ${ }^{70}$ Adomnanus ad Hiberniam pergit et dedit Legem Inocentium populis.

\footnotetext{
${ }^{64}$ AU 673.5, AT [673].4, CS [673].3.

${ }^{65}$ ARC $\$ 130.3$, AClon 657.3.

${ }^{66}$ ARC §136.1, FAI §41, AClon 664.3, AFM 667.2. Iona to Inishboffin.

${ }^{68}$ ARC $\$ 148.4$ and $\S * 150.4$, FAI $\S 95$, AClon 682.1, AFM 684.4.

${ }^{69}$ ARC $\$ 153.1$, FAI $\$ 111$.

${ }^{70}$ ARC §156.1, AI 696.1, FAI §135, Mionannála 697.
}

${ }^{67}$ It is not clear from this entry that Columbanus was travelling from Britain to Insola Uaccae Albae (Inishboffin), but Columbanus was the Colmán in Bede's Historia ecclesiastica gentis Anglorum III.25 (Bede's Ecclesiastical History of the English People, ed. and trans. Bertram Colgrave and R.A.B. Mynors [Oxford, 1969; rev. imp., 1991], 296-309), who was bishop of Lindisfarne in Northumbria during the Synod of Whitby in 664. According to Bede's History, after the Council Colmán went 'to his native land' (III.26) in 664 (V.24), and Iona (IV.4), before founding monasteries at Inishboffin and Mayo in Ireland in 667 (IV.4): Bede's Ecclesiastical History, ed. and trans. Colgrave and Mynors, $308-9,564-5$, and 346-7. It is quite possible that the entry in these Irish chronicles was referring to a journey from 
AU 698.4: Expulsio Ainfcellaig filii Ferchair de regno, et uinctus ad Hiberniam uechitur.

AU 699.3: Tarain ad Hiberniam pergit.

AT [733].4: ${ }^{71}$ Flaithbertach clasem Dal Riada in Iberniam duxit, et c<ae>des magna facta est de $<e>$ is in insola hOine uibi hi trucidantur uiri - Concobar mac Lochéni et Branchú mac Brain; et multi in flumine demersi sunt, <quod> dicitur in Banna.

AU 734.7: Dún Leithfinn distruitur post uulnerationem Dúngaile; et in Hiberniam a potestate Oengusso fugatus est.

In the entries describing journeys from Britain to Ireland (Group 3) the destination, Hibernia (and in one instance Inishboffin, Co. Galway), is mentioned, but the point of departure is not. ${ }^{72}$ As in the case of Group 2, describing voyages from Ireland to Britain, this should not be regarded as indicative of origin, but when the prepositions are studied an interesting pattern emerges. The preposition in is used for journeys from Ireland to Britain, but only twice for voyages from Britain to Ireland, whereas ad is employed in the majority of journeys from Britain to Ireland (six times out of eight if excluding, and seven times out of nine if including, the journey of Columbanus to Inishboffin), but not for journeys in the opposite direction. ${ }^{73}$ The pattern could indicate that in these travel-entries ad often had a slightly different semantic range from in, perhaps meaning 'away to' while in was more perspective-neutral; therefore the use of $a d$ for journeys from Britain to Ireland could indicate that the chroniclers responsible for these entries were based in Britain.

The implication of this study of the phraseology of the travel-entries before 740 is that they were produced somewhere in Britain (except perhaps the entry on Cumméne's journey to Ireland

\footnotetext{
${ }^{71}$ FAI $\$ 221$, AClon 730.1, AFM 728.3.

72 Another entry which could be considered a travel-entry is AU 664.2 (Mortalitas in Hiberniam peruenit in kl. Augusti), AT [664].2, CS [664].2, but it is uncertain whether the plague came from Britain.

${ }^{73}$ In Group 1, ad occurs in one out of three journeys from Britain to Ireland.
} 
in AT [661].4, CS [661].4). This is dependent on the view that most of these entries should be considered as a single group, and there are two reasons for this: first, many of them manifest an interest in Columban ecclesiastics; secondly, they share vocabulary and stylistic features which together indicate that they all came from a single source. Nine of the eighteen journeys concern people or relics of the Columban familia; the voyage of Máel Rubai to Britain is the only other travel-entry involving an ecclesiastic. ${ }^{74}$ One entry about a journey by Adomnán to Ireland includes the detail that this event occurred in the fourteenth year after the death of Adomnán's predecessor, Faílbe, information which would have been of most interest within the Columban familia. ${ }^{75}$ Given that Iona is the only Columban centre with detailed entries during this period, it is likely that the travel-entries were written there. ${ }^{76}$

The vocabulary of the travel-entries provides more evidence that they should be regarded as a group. Two of the entries on Adomnán's journeys and two others include the verbal form pergit, from pergere, 'to travel' ${ }^{77}$ These four entries, all from AU 692 to 700, are the only instances where pergere is found in Irish chronicles before A.D. 912; therefore it is very likely that they were all derived from the same source.

Two other features, de regno ('from the kingship') and expulsus or expulsus est ('was driven out/away', 'was expelled'), usually found together, occur in a few of these entries, including

\footnotetext{
${ }^{74} \mathrm{AU}$ 671.5, AT [671].4, CS 671.4. The entries about the Columban jurisdiction are: AT [661].4; AU 668.3 (AT [668].1); AU 673.4 (AT [673].3); AU 676.5 (AT [676].3); AU 687.5 (AT [687].5); AU 692.1 (AT [692].1); AU 697.3 (AT [697].3); AU 727.3 (AT [727].5); AU 730.3 (AT [730].1).

${ }^{75}$ AU 692.1, AT [692].1, CS [692].1.

${ }^{76}$ Other Columban houses mentioned before 740 are: Derry (AU 546), Rechru (AU 635.3, AT kl 138 [635].2, ARC §114.1, AFM 630.5); Lindisfarne (AU 632.4, AT kl 136 [632].3, CS [632].2, AFM 627.3; AU 651.1, AT kl 152 [651].1, CS [651].2, ARC §121.1, AClon 648.1; AU 668.3, AT [668].1, CS [668].2, ARC §136.1, FAI §41, AClon 664.2, AFM 667.2; AU 676.1, AT [676].1, CS [676].1, ARC \$141.2, AClon 672.2, AFM 674.2, the obit of Columbanus, bishop of Inishboffin, who left Lindisfarne after the Council of Whitby). None of these entries, except for the travel-entry of Columbanus (AU 668.3, AT [668].1, CS [668].2, ARC §136.1, FAI §41, AClon 664.2, AFM 667.2), gives extra details or is after 680 .

${ }^{77}$ AU 692.1, AT [692].1, CS [692].1, ARC §153.1; AU 697.3, CS [697].1 (in Gaelic in AT [697].3); AU 699.3; AU 700.5, AT [700].4, ARC $\S * 158.4$.
} 
AU 700.5 (AT [700].4), which also has pergit, and AU 714.4 (AT [714].4, CS [714].2), which has de regno expulsus est. ${ }^{78}$ The only other occasion where de regno expulsus est is found is in AU 697.1 (ARC $\S^{*} 156.3$ ), on the expulsion of the Pictish king Tarachin. ${ }^{79}$ If, as seems likely, Tarachin is the same person as the Tarain who travelled to Ireland two years later (according to AU 699.3), and if these two entries derive from the same source, then the use of pergit in the travel-entry provides more evidence that the same chroniclers based in Iona were responsible for the entries with pergit, de regno, and expulsus est. ${ }^{80}$ The lack of later examples of these features makes it unlikely that they were intruded into these entries at a later date.

De regno without the kingship being specified is found elsewhere only in an entry shared by AU and AT, AU 672.6 (AT [672].5), recording the expulsion of the Pictish king Drest son of Donuel. This entry has the noun expulsio instead of the verb expulsus est. In AT, AU, and CS, expulsio only occurs elsewhere in AU 717.4 (AT [717].5, CS [717].2), which is shared by AU and the Clonmacnoise group, as well as in AU 698.4, and twice in AT [726].4, all of which describe

\footnotetext{
${ }^{78}$ Expulsus est is the perfect passive form of the verb expellere.

${ }^{79}$ AT [697].1 is a Gaelic translation undertaken in the twelfth century or later of AU 697.1. Expulsus also is found in ARC $\$ 272.4$.

${ }^{80}$ The Series longior Pictish king-list (ed. Anderson, Kings, 248, 262-3) gives Taran filius Entifidich a reign of four yours after Bridei son of Bile, whose obituary is noted in AU 693.1 (AT [693].2, AI 690.1, FAI §115). This would probably make AU 697, in which the deposition of Tarachin is recorded, the correct annal for the end of his reign. It has been argued by Henderson, 'North Pictland', 47, that the two entries about Tarain/Tarachin were accounts of the same event by two different chroniclers, with AU 699.3, which is unique, being from her hypothetical 'Applecross Chronicle' and the other (AU 697.1, AT [697].3) from 'The Chronicle of Ireland'. While, as Henderson has stated, the different name-forms support this theory, the different contents of the entries make it possible to envisage that Taran was expelled from his kingship, but that only two years later did he decide to go to Ireland. Adomnán, Vita $S$. Columbae tripartita, II. 23 (Adomnan's Life of Columba, ed. and trans. A.O. Anderson and M.O. Anderson [Edinburgh, 1961; 2nd edn, Oxford, 1991], 126-7) mentioned an exile called Taran from a noble Pictish family, who was entrusted to a rich man called Feradach on Islay, but subsequently murdered by his host. Feradach was then killed through the power of Columba. I am indebted to James Fraser for allowing me to see a draft of the relevant part of his paper 'Adomnán, Cumméne Ailbe and the Picts', Peritia 17/18 (2003/4) 183-98, where he has suggested that, in as much as this text was written in the final years of the seventh century or the opening years of the eighth, it may reflect events after Taran was expelled from his kingship. The episode could be a warning that those looking after the contemporary Taran should not betray him to his enemies because Columba, through his Ionan successors, would wreak his vengeance. It is, therefore, quite likely that after his expulsion Taran spent some time in Dál Riata before travelling to Ireland (Fraser has suggested that Taran stayed at Iona, but he could also have stayed elsewhere in Dál Riata before going to Ireland). This would support the theory that the two entries on Taran described two separate events and were part of a single source.
} 
events in northern Britain. AU 717.4 (AT [717].5, CS [717].2), ${ }^{81}$ Expulsio familiae Iae trans Dorsum Brittaniae a Nectano rege, on the expulsion of familia Iae across Dorsum Britanniae (the ridge following the watershed north of Balquhidder between the rivers flowing west to the Atlantic and those flowing east to the North Sea) ${ }^{82}$ by the Pictish king Nectan son of Derilei in 717 , is highly unusual, because the Irish chronicles very rarely give information on the consequences of ecclesiastical politics. This entry, then, provides evidence that the source behind entries with expulsio, expulsus est, de regno and pergit had a special interest in the life of the Ionan familia, and perhaps in Pictish affairs as well.

AU 717.4 (AT [717].5, CS [717].2) also provides a link to a large body of entries with features highly characteristic of the record for this period. It has Nectanus rex without specifying whom Nechtan ruled, a use of rex characteristic of the entries for northern Britain in the 710s and 720 s, but very rarely employed elsewhere. ${ }^{83}$ This use of rex seems to indicate sufficient familiarity that identification of the kings' lordship was considered unnecessary; so it is striking that this feature occurs only with Pictish kings. This could be indicative of a Pictish written source, but alternatively it could reflect the Pictish kings' importance to the Ionan community. ${ }^{84}$

Rex without a specified kingship is found in a group of entries sharing the use of present passive verbs and the prepositions apud and iuxta. These features are found in combination in

\footnotetext{
${ }^{81}$ ARC $\$ 170.1$.

${ }^{82}$ Richard Sharpe, Adomnán of Iona. Life of St Columba (London, 1995), 332-3, n. 283. For discussion of the meaning of Dorsum Brittanniae, see Philip Dunshea, 'Druim Alban, Dorsum Brittanniae - 'the Spine of Britain', The Scottish Historical Review 92.2 (October 2013), 275-89.

${ }^{83}$ This feature is found at AU 713.7, AT [713].8; AU 717.4, AT [717].3, ARC \$170.1; AU 726.1, AT [726].1; AU 728.4 (rewritten at some point after 1113 in AT [728].4); and AU 787.6. There are no directly parallel instances of this feature from 800 to 911; although rex or rí are sometimes not immediately followed by a population-group, territorial name, or place-name to identify the kingship in AU 827.4, 831.6, 858.4, and 901.3, the sentence usually makes clear which kingship is intended in these entries. A possibly closer example is AU 803.6, but, unlike the examples describing events in northern Britain, the king's name is not given in this entry. This usage of rex or rí is also found in ARC $\$ * 125.2$ (for Penda of Mercia), AI 436, 604.3, 612.4, 700.2, 718.1 .

${ }^{84}$ However, perhaps the closest parallel to this feature is the use of de regno, also found without the kingship being specified, but de regno is employed for Irish and Dalriadic, not just Pictish, kings.
} 
INR 69[1] EVANS: Page 21 of 57

records of the following five events, which indicates that they come from the same source.

Presumably, this source may have included many of the other entries with only one of these features.

AU 713.7 (AT [713].8): ${ }^{85}$ Tolargg filius Drostain ligatur apud fratrem suum Nectan regem.

AU 714.2 (AT [714].2): Dún Ollaigh construitur apud Selbachum.

AU 717.4 (AT [717].5, CS [717].2): ${ }^{86}$ Expulsio familiae Iae trans Dorsum Brittaniae a Nectano rege.

AU 726.1 (AT [726].1): Nectan m. Deirile constringitur apud Druist regem.

AU 728.4 (AT [728].4 rewritten in Gaelic): ${ }^{87}$ Bellum Monidchroibh inter Pictores inuicem, ubi Oenghus uictor fuit, et multi ex parte Eilpini regis perempti sunt. Bellum lacrimabile inter eosdem gestum est iuxta Castellum Credi, ubi Elpinus efugit.

The use of Latin present passive forms of the verb is another significant feature in the Irish chronicles in the period from 698 to 738 . When one excludes verbs used regularly to introduce people or poems (for example forms of dicere, nominare, and uocare) and entries copied closely from other sources, such as Bede's Chronica maiora, there are 26-29 present passive forms overall in $\mathrm{AU}$ and AT (or CS) before A.D. $1130 .{ }^{88}$ Four of these occur before 660, but the great majority

${ }^{85}$ AClon 710.4.

${ }^{86}$ ARC $\$ 170.1$.

${ }^{87}$ AClon 725.1.

${ }^{88} \mathrm{AU}$ 431, 439 (CS [439], AI 439, ARC §6), 630.2, 643.7 (CS [643].1, ARC left margin §*118.4), 698.4, 703.4, 712.11 (AT [712].8), 713.7 (AT [713].7), 714.2 (AT [714].2), 714.3 (AT [714].3), 716.4 (AT [716].3), 725.2 (AT [725].2), 725.3 (AT [725].3), 726.1 (AT [726].1), perhaps 727.4 (AT [727].4, ARC §177.2), 727.5 (twice, also in AT [727].5, ARC §*177.3, FAI §199), 731.3 (AT [731].3), 734.5, 734.6, 734.7, 738.3, 738.4 (AT [738].4), 750.6. Present passives found only in the Clonmacnoise-group are AT [718].6 (CS [718].3, ARC \$171.4), 733.4, 764.12 (ARC $\S * 195.3)$. Present passives are also found in AI 451.1; ARC $\S 9, \S 89, \S * 92.2, \S 94, \S * 169.3$; FAI $\$ 97,143$. In annals for the mid-ninth century CS has martirizatur in CS [854].2 and [856].8, where AU 854.3 and 856.8 have martirizat. Entries from Bede's Chronica maiora (De temporum ratione, §66) - Bedae Venerabilis Opera. Pars VI. Opera Didascalia 2, 3 vols (Turnhout, 1977-80), 495-535- are AT kl 113 [607].1 from Chronica maiora §536, AT kl 119 [613].2 from Chronica Maiora §540, AT [683].2 from Chronica maiora §569. AU 531 (also in AT kl 35 [528].2) may have come from either Bede’s Chronica maiora \$517 or Isidore's Chronica maiora, $\$ 400$ (Chronica minora. Saec. IV.V.VI.VII, ed. Theodor, Mommsen, 3 vols [Berlin, 1891-8], II, 391-499). 
of present passives (20 or 21) is found from 698 to 738, being especially common from 712 onwards. After 740 present passives are rare; there are only two instances between 740 and 800 and two uncertain cases in the ninth century. In contrast, perfect passives, which could be used as alternatives to present passives, continue to appear regularly in AU to 1130 and in the Clonmacnoise-group to the early tenth century. This evidence indicates that present passives were contemporary features of one or more chronicle between 698 and 738.

A similar concentration of use of the preposition apud - as T. F. O'Rahilly first noticed - is found in AU, AT, and CS in the period from 695 to 731. Apud is found twenty-one times in AU, twelve times in AT, and three times in $\mathrm{CS}^{89}$ Fourteen of those in AU and seven of those in AT occur from AU 695 to 731, and mainly in the 710s. The meaning of apud in these entries is either 'among' or 'by', rather than 'at' or 'near'. ${ }^{90}$ It is found five times between 731 and 912 in AU, but not in any concentration which suggests that an editor before 912 included apud while rewriting earlier entries. ${ }^{91}$

\footnotetext{
${ }^{89}$ O’Rahilly, Early Irish History and Mythology, 256-7. However, O'Rahilly's suggestion that they were written by a single chronicler, Cochul Odhor, described as scriba familie Benncair in his obit in AU 730.9, is unlikely to account for those, especially the apud in AU 731.4, written after his death. Apud is found in AU 454; AT kl 52 [544].4; AU 669.2, AT [669].2, CS [669].2; AU 695.1; AU 701.8; AU 710.4; AU 710.6; AU 711.3, AT [711].3; AU 712.5; AU 712.9, AT [712].6; AU 713.7, AT [713].7; AU 714.2, AT [714].2; AU 714.5, AT [714].5; AU 714.8, AT [714].8; AU 719.5, AT [719].3, CS [719].1; AU 726.1, AT [726].1; AU 731.4; AU 787.6; AU 804.5; AU 811.6; AU 854.3, CS 854.2, ARC §248; AU 867.8. ARC §*170.5 also has apud. Items from Bede's Chronica maiora with apud are AT kl 72 [565].2 from Chronica maiora §523, AT kl 119 [613].3 (twice) from Chronica maiora §541, and AT [704].2 from Chronica maiora §568. AT has ten of the AU entries with apud, but AT [726].1 also has abp with an abbreviationstroke, which might originally have been apud. AT [711].3 has $a b$ and AT [695].1 has Gaelic do rather than apud. CS has four of the apud entries in AU, but CS [695].1 (the entry equivalent to AU 695.1) has ó instead. From the use of apud in both AU and the Clonmacnoise-group it is likely that apud in these entries was inherited from 'The Chronicle of Ireland'.

${ }^{90}$ It is not followed by a place-name in any instances (except AT [704].2, from Chronica maiora, §568), which indicates that 'near' or 'at' was not the intended meaning of apud. In at least twelve instances the meaning 'by', indicating the instigator of an action, is clearly intended, with apud often being followed by a personal name. In one instance, AU 669.2 (AT [669].2, CS [669].2), which reads Itarnan et Corindu apud Pictores defuncti sunt, 'among' is the probable meaning, but in other cases apud might mean either 'by' or 'among': cf. D. Dumville, 'Cethrí prímchenéla Dáil Riata’, Scottish Gaelic Studies 20 (2000), 170-91, at 189.

${ }^{91}$ From 760 to 911 other prepositions are found instead of apud; alab occurs in AU sixty-eight times, while Gaelic la is found twenty-two times.
} 
The Latin preposition iuxta, meaning 'next to', 'beside', is found five times before 1100, with four of these occurring from 728 to $737 .{ }^{92}$ Iuxta appears in only one entry shared by both AU and the Clonmacnoise-group, but this instance, other features shared by these entries, and the concentration of iuxta-entries in such a short period together make it likely that in the other cases the iuxta found in AU was replaced with Gaelic oc in the Clonmacnoise-group. Three of those from 728 to 737 concern events in northern Britain, while the other entry in that period describes a battle in Ireland among Síl nÁedo Sláine. In all the entries with iuxta this preposition is followed by a place-name, the first word of which is in Latin. ${ }^{93}$ Both AU 728.4 and 737.4 have Latin personal names, the noun pars meaning 'side' rather than 'part', and gestum est, 'took place'. 94 Also, the three battle-entries before 740 which include iuxta all contain a formula employing the preposition inter to introduce the participants. ${ }^{95}$ All these textual links make it likely that the instances where iuxta is found from 728 to 737 were part of a single chronicle.

When entries with present passives, apud, iuxta, and rex without a specified kingship are compared with those with pergit, de regno, expulsus est, and expulsio, it becomes clear that both groups share a number of characteristics indicative of a single source. From the preceding analysis it has emerged that entries with pergit, de regno, expulsus est and expulsio display a detailed interest in Ionan events, but attention to Ionan affairs is also evident in entries with present passives. AU 727.3 (AT [727].5), a travel entry on the carrying of the relics of Adomnán to Ireland and the renewal of his law (which is followed by their return in AU 730.3, AT [730].1), has two

\footnotetext{
${ }^{92} \mathrm{AU} 728.4$ (ac in AT [728].5); AU 729.2; AU 734.6; AU 737.4, AT [737].4; AU 819.2 (ic in CS [819].2). It is possible that iuxta means 'at' if it corresponds with the Gaelic preposition oc, meaning 'at', 'next to', 'beside', but it is clear that in AU 729.2 and AU 737.4 'at' was not intended. A correspondence with a Pictish preposition in AU $728.4,729.2$, and 734.6 should also be considered a possibility. Iuxta is also found in FAI $\$ 180$.

${ }^{93}$ See below, p. $\$ \$$ (16).

${ }^{94}$ For Latin personal names, see below, pp. \$\$-\$ (16).

${ }^{95}$ The formulae inter $\mathrm{X}$ et $\mathrm{Y}$, 'between $\mathrm{X}$ and $\mathrm{Y}$ ', and inter $\mathrm{X}$ inuicem, 'among $\mathrm{X}$ themselves' (used if the conflict was viewed as internal) are common from the 720 s until the late eighth century.
} 
present passives, transferuntur and renouatur. This entry complements AU 697.3 (AT [697].3, CS [697].1), on the promulgation of this law, which has pergit. ${ }^{96}$ Also, AU 716.4 (AT [716].3), on the changing of Easter-calculation at Iona, has the present passive comotatur. ${ }^{97}$ As I have argued above,${ }^{98}$ these events would have been of interest mainly to Iona and its associated establishments.

These entries are all shared by AU and AT/CS. If entries unique to either AU or the Clonmacnoise-group are taken into consideration, however, then the conclusion is strengthened further: AU 698 (Expulsio Ainfcellaig filii Ferchair de regno, et uinctus ad Hiberniam uechitur) has both de regno and a present passive; AT [733].4 has the present passive trucidantur. Both of these entries describe journeys. In addition, CS [718].3 (AT [718].6), Tonsurae corona super familiam Iae datur, continues the interest in reform at Iona, already found in the shared entry in annal 716 about the change in the Easter-reckoning, and has the present passive datur.

Aside from their Ionan interest, both sets of features display the same geographical emphasis, dealing mainly with events in northern Britain - but also sometimes Irish affairs. In the first set (with present passives, apud, iuxta, and rex without a specified kingship), five of the entries shared by AU and the Clonmacnoise-group involve journeys between Ireland and Britain, three are solely about events in northern Britain, but none is just concerned exclusively with Ireland. ${ }^{99}$ The same is the case for the second set: all the examples of rex on its own occur with Pictish kings, and three of the four iuxta entries concern the Picts, with only one example of an Irish event. More of the shared entries with present passives from 698 to 738 describe events in Britain rather than Ireland: six of these entries concern events in Britain, two involve people from both Britain and Ireland,

\footnotetext{
${ }^{96}$ Duncan, 'Bede, Iona', 13-14, used a combination of AT's entry and AI [696].1 to reconstruct the original form of this entry, but the fact that CS [697].1 is more or less identical to AU 697.3 makes it very likely that AU and CS retain the usage of 'The Chronicle of Ireland' in this entry.

${ }^{97}$ It is perhaps significant that only Iona is stated to have changed its Easter dating.

${ }^{98}$ See above, pp. \$\$ $\$$ \$.

${ }^{99} \mathrm{AU} 698.4$ and 699.3, which are found only in AU, both involve people travelling from Britain to Ireland.
} 
and only two describe events exclusively in Ireland. ${ }^{100}$ Apud is found in five entries for Irish events and on five occasions for events in northern Britain; but, if entries unique to AU are included, we have records of four more events in northern Britain but only one more Irish event. Entries with both these sets of features display a similar interest in both northern Britain and Ireland, including travel between the two islands; but their focus is mainly on northern Britain.

Other stylistic traits, notably the use of familia, and Latin for personal and place-names, are shared by entries with both these sets of features; this offsets to a large extent the lack of overlap between them, except in the case of AU 717.4 (AT [717].3, CS [717].2), which has both rex without a full title and expulsio. These other common characteristics provide weaker evidence, because they are also found later in the chronicles; but they increase the likelihood that there was a single source. Familia, denoting an ecclesiastical community, is often used with the words 'Iona' and 'Columba', but it also appears after 740 in Irish entries. ${ }^{101}$ Familia Iae is found in AU 717.4 (AT [717].3, CS [717].2) with expulsio and rex without a specified kingship, in AT [718].6 with a present passive, and familia (unqualified) appears in AU 714.8 with apud. ${ }^{102}$

Another feature of the annalistic record for northern Britain is the use of Latin for personal and place-names which had Gaelic equivalents, although this is also found for Irish events at this time as well as later in the eighth century. ${ }^{103}$ AU 692.1 (AT [692].1, CS [692].1) and 697.3 (CS [697].1;

\footnotetext{
100 The following events are of uncertain location, but more likely to have taken place in northern Britain: AU 703.4; AU 714.3, AT [714].3; AU 725.2, AT [725].2; AU 727.4, AT [727].4. Present passives in entries found only in the Clonmacnoise-group relate one event in northern Britain and one involving Britain and Ireland; and of entries found only in AU three concern events in northern Britain, one concerns Ireland, and one involves both areas.

${ }^{101}$ See Colmán Etchingham, Church Organisation in Ireland, A.D. 650-1000 (Maynooth, 1999), 127, 173-7, for the use and meaning of familia in Gaelic chronicles, and 126-30 for its use elsewhere.

${ }^{102}$ Elsewhere, familia is found in AU 641.1 (for Iona), 691.5 (Iona), 719.9 (familia Suibne in Armagh), 727.3 (the secular familia Echdach of Dál Riata), 729.2 (the secular familia Oengussa of the Picts), 730.9 (Bangor), 749.7 (Iona), 764.6 (Clonmacnoise and Durrow), 776.11 (Durrow), 806.8 (Iona), 807.9 (Cork and Clonfert), 811.2 (Tallaght), 817.7 (of Columba).

${ }^{103}$ For the use of Latin personal names, see F. J. Byrne, 'Chiasmus and hyperbaton in The Annals of Ulster', in $O g m a$. Essays in Celtic Studies in Honour of Próinséas Ní Chatháin, ed. Michael Richter and J.-M. Picard (Dublin, 2002), 54-64, at 62-4, where he has suggested that these could all be from 'The Chronicle of Iona', except perhaps AU 737.4, AT [737].4 (but see above, p. \$ [14-15], for other features shared by this entry and those with iuxta).
} 
AT [697].3 has Adomnán) have the Latin Adomnanus as well as pergit, and AU 717.4 (AT [717].3, CS [717].2) also has Nectanus, Dorsum Brittaniae (for Druim Alban). ${ }^{104}$ The personal names Selbachus (AU 712.5; AU 714.2, Selbach in AT [714].2) occurs with apud, Adomnanus (AU 727.5) and filius Cuidini (731.1; mac Cuitine in AT [731].3) with present passives, Elpinus (AU 728.4; Ailphin in AT [728].5), and Cernachus (AU 737.4, AT [737].4) with iuxta, and the placenames Campus Manonn (AU 711.3, AT [711].3) with apud, Castellum Credi (AU 728.4; Caislen Credhi in AT [728].5), Stagnum Loogde (AU 729.2), and Lapidem Ailbe (AU 737.4, AT [737].4) with iuxta; therefore both sets of features are found with these characteristics.

The relative lack of overlap between entries with pergit, expulsus est, and expulsio on the one hand and entries with present passives, apud, iuxta, and rex without a kingship specified on the other can largely be explained by their general occurrence in different periods; the former are mainly found before 700 , whereas most of the latter are in entries from 710 to 740 . Indeed, the similarity of interests displayed in these entries, especially in Iona's affairs, and their common stylistic features, indicate that both groups derived from a single source, whose style evolved over the period from 660 to 740 . The contents of that source's entries cover most of the subjects which Bannerman showed to be typical of the record for northern Britain from 660 to 740: travel entries, successions at Iona, drownings, and captures, the building, besieging, and destruction of forts. ${ }^{105}$ Given Iona's close links with Ireland, however, it is not unexpected that that source also included

\footnotetext{
${ }^{104}$ For the identification of Dorsum Brittaniae as Druim Alban, see William J. Watson, The History of the Celtic Place-names of Scotland (Edinburgh, 1926), 12. Iae, found in familia Iae (AU 717.4, CS [717].2, AT [717].3 with expulsio and rex without a specified kingship; CS [718].3, AT [718].6, with a present passive) and Failbhei (AU 692.1, AT [692].1, CS [692].1) could be Latin genitive singulars, if they are not Gaelic (see ibid., 87-90, for forms of the name 'Iona').

105 See above, pp. \$\$-\$ (6-7) for succession entries and pp. \$\$-\$\$ (8-11) for travel entries. The characteristic features of 'The Chronicle of Iona' occur in entries involving someone's capture in AU 713.7, AT [713].7, AClon 710.4; AU 725.3, AT [725].3; AU 726.1, AT [726].1; AU 731.3, AT [731].3; AU 734.5, AT [734].5, AU 734.6, the drowning of people in AU 734.5, AT [734].5; the building of places in AU 703.4, AT [703].4; AU 714.2, AT [714].2; AU 725.2, AT [725].2; and the destruction of places in AU 714.3, AT [714].3. None of the shared entries, but a number of entries only found in AU, has these characteristics in siege entries.
} 
a record of some Irish events. ${ }^{106}$ There is little evidence that a source other than a 'Chronicle of Iona' underlies any of the entries for northern Britain shared by AU and the Clonmacnoise-group from 660 to 740 .

After 740 the number of entries concerning northern Britain falls dramatically: there are only eleven items shared with CS or AT about events in northern Britain from 741 to 800, partly the result of the lacunae in CS from 722 to 804 and AT from the middle of 766 to $973 .{ }^{107}$ This makes it much more difficult to draw meaningful conclusions from the style of these entries, but there are a few which display some similarity to those 'The Chronicle of Iona': AU 749.4 (AT [749].11) ${ }^{108}$ continues the interest in drownings and has the phrase familia Iae; AU 750.4 (in Gaelic in AT [750].5), ${ }^{109}$ describing a battle between Picts and Britons, gives the detail that Talorggan mac Forggusso was the brother of Oengus, thus continuing a familiarity with and interest in the Pictish

\footnotetext{
${ }^{106}$ For an account of Iona's founding and development, including its continued interest in Ireland, see Máire Herbert, Iona, Kells, and Derry. The History and Hagiography of the Monastic familia of Columba (Oxford, 1988), 9-67.

${ }^{107}$ If other Irish chronicles are included then there are twenty six or twenty seven entries shared with AU, with the following entries being added to the total: AU 766.6, ARC §197.3; AU 767.5, ARC §198.4, AFM 762.5; AU 768.7, AFM 763.9; AU 772.5, ARC \$202.2; AU 775.1 (which includes two separate events about northern Britain), ARC $\S * 203.5$ and $\S * 205.2$, AFM 770.4; AU 776.6, AFM 771.9; AU 778.7, AClon 769.4, AFM 771.18; perhaps AU 778.11, AFM 773.7; AU 780.5, ARC §*211.2, AClon 773.1; AU 781.3, AClon 778.2, AFM 776.7; AU 782.1, AFM 777.4; AU 782.2, AFM 777.14; AU 790.1, AFM 785.2, AU 790.1, AFM 785.2; AU 791.1, AFM 786.4; AU 792.4, AFM 787.4. AU 757.9 (AT [757].9), Lex Colum Cille la Sléibéne, could potentially also have been included, but Sléibéne was probably in Ireland when this happened, because AU 754.3 (AT [754].4) has the journey of Sléibéne to Ireland, and ARC §191.3 (AT [758].2) has his journey back (Anderson, Kings, 8, n. 32, argued that de, as is found in ARC $\S 191.3$, rather than AT's in, was probably original; but she did not refer to the ARC entry). The entry on the law was probably written in Ireland, because interest in cáin-lawmaking and its phraseology are typical of the Irish record in this period. For a discussion of these entries, see T. M. Charles-Edwards, The Early Mediaeval Gaelic Lawyer (Cambridge, 1999), 43-8. AClon and ARC, both of which are likely to have been largely reliant on Clonmacnoisegroup sources, have a number of entries for Britain found elsewhere only in AU in the section where AT and CS are lacunose: ARC §§198, 202, 203, 205, 211; AClon 769.4, 773.1, 778.2, 791.5, 793.2, 795.1. AFM 754.4 (equivalent to A.D. 759) uniquely has Feidhlimidh no Failbhe, abb Iae, d'ecc iar secht m-bliabhna ochtmoghat a aeisi ('Feidlimid or Faílbe, abbot of Iona, died at the age of 87 years'). As James Fraser (From Caledonia, 372-3) has argued, it is possible, that a number of clerics of Lismore in the annals refer to people from Lismore Mo Luóc in Dál Riata rather than Lismore Mo Chutu in Munster, Ireland. If so, then the record for northern Britain, and Lismore in particular, would be substantially increased. However, the appearance of these items often in lists of obits, or with a common word like mors (for instance, for Findchú in AU 757.4, AT [757].4) means that it is difficult to study these items through an analysis of vocabulary.

${ }^{108}$ AFM 744.8

${ }^{109}$ AClon 746.2.
} 
king Unuist son of Uurguist present in 'The Chronicle of Iona' before $740 .{ }^{110}$ Also, there is an entry (AU 754.3, AT [754].4) ${ }^{111}$ on the journey of Sléibéne, abbot of Iona, to Ireland, which is similar to the earlier travel entries. ${ }^{12}$ These are all features which could indicate continuation of 'The Chronicle of Iona' as a source; but the evidence is not conclusive.

Other entries show more continuity with the style of Irish entries before 740. AU 752.1 (AT [752].1) ${ }^{113}$ has ancorita, and in AU 752.2 (AT [752].2) Cumméne ua Bécce is described as a relegiosus of Eigg. ${ }^{114}$ These titles are used before 740 for ecclesiastics from Ireland, but not those from northern Britain, and so it is likely that all of them were written in Ireland. ${ }^{115}$ The shared entries overall provide seemingly contradictory evidence for being written at Iona and Ireland, but because the majority of the entries for northern Britain from 740 to 800 is only found in one textual group, the sources of these entries will be dealt with in more detail after the entries unique to either AU or the Clonmacnoise-group have been discussed.

Entries unique to 'The Annals of Ulster'

\footnotetext{
${ }^{110}$ AT [750].5 states that both Talorgan and his brother died in this battle. AU, which identifies Talorgan as frater Oengussa, is probably correct in stating that only Talorgan died.

111 ARC $\$ 191.3$.

112 See above, $\$ \$ \$-\$ \$, \$$ pp. $(8-11,23-4)$.

113 AFM 747.2

114 The B manuscript of AU lacks the reference to Eigg.

115 Bannerman, Studies, 20. Sapiens, found in a large number of obits of Irish ecclesiastics from about 660 onwards, could be another Irish feature, although the obits of Aldfrith, king of the Northumbrians, in AU 704.3 (ARC §*162.2) and Cú Chuimne of Iona in AU 747.5 (AT [747].6) also have this word. For Aldfrith's links with Ireland, see H. Moisl, 'The Bernician royal dynasty and the Irish in the seventh century', Peritia 2 (1983), 103-26, at 119-24; but Moisl's argument that Uí Néill helped Aldfrith gain his throne is not conclusive. It is arguable that Cú Chuimne collaborated with Irishmen in the production of Collectio canonum Hibernensis, an important collection of ecclesiastical law: see T. M. Charles-Edwards, Early Christian Ireland (Cambridge, 2000), 265, and Die irische Kanonensammlung, ed. F. W. H. Wasserschleben (2nd edn, Leipzig, 1885). These contacts allow that Irish chroniclers were sufficiently interested to record obits of both these people; but it is also possible that chroniclers in northern Britain, using sapiens far less frequently, wrote these two entries. For a discussion of sapiens in Gaelic chronicles, see Charles-Edwards, Early Christian Ireland, 264-71.
} 
As I have already mentioned, other sources have been proposed by various scholars for some entries, including chronicles kept at Applecross, at a Columban centre other than Iona, and in Pictland. ${ }^{116}$ Most of these theories are based on arguments that entries found in only one textual group were derived from other sources; in the following discussion I shall therefore assess whether these unique entries were part of 'The Chronicle of Ireland' and whether they contain features characteristic of 'The Chronicle of Iona'.

In the early 1970s Isabel Henderson studied the pattern of unique and common material in AU and AT before 750 and proposed that there was a separate source kept in Applecross from about 675 to about 750, included in AU but not in the Clonmacnoise-group, although she was uncertain when and how this had come to be incorporated in an ancestor of AU. ${ }^{117}$ She contrasted the large number of secular entries unique to AU for Dál Riata and the Picts from 675 to 750 with the situation before 675, when AT contains a number of entries with extra details, and the short period $724-733$ when there are entries unique to AT. ${ }^{118}$ Henderson argued that this pattern was artificial and therefore unlikely to have been due to omissions from the Clonmacnoise-tradition of chronicling. From the interest displayed, in the entries unique to AU, in events concerning Cenél Loairn and Skye, Henderson argued that they were written in Applecross and begun soon after its foundation in $673 .^{119}$

There are factors, however, which indicate that these entries were part of 'The Chronicle of Iona': they have the same vocabulary and interests as that chronicle, their distribution throughout the period from 660 to 766 , and their positions in each annal render it likely that they share a textual history with the Irish events recorded uniquely in AU. The sources of many entries unique

\footnotetext{
116 See above, pp. \$\$ $\$$ \$.

117 Henderson, 'North Pictland'.

118 Ibid., 44-5.

119 Ibid., 48.
} 
to AU are not formally identifiable, because they are very short, consisting of obituary entries with commonplace words or phrases, for instance moritur or iugulatus est, and brief entries about the burning and plundering of places, beginning with combustio or obsessio. Many of the lengthier entries contain stylistic features typical of 'The Chronicle of Iona'; this contrasts with the low number of other words characteristic exclusively of notices of events in northern Britain, which are found only in AU. The use of percutio ('smiting') in AU 741.10, aithbe flatho ('ebbing of [the] lordship') in AU 750.11, and familia denoting a secular grouping in both AU 727.3 (familia Echdach) and AU 729.2 (familia Oengussa) ${ }^{120}$ could indicate a separate source for these entries, but these differences are not sufficient or numerous enough to identify a separate style for these entries, especially in AU 727.3 and AU 729.2 which have other vocabulary typical of 'The Chronicle of Iona' ${ }^{121}$

In contrast, many of the other entries contain vocabulary, often typical of 'The Chronicle of Iona', which is found elsewhere in Irish entries and in entries surviving in both AU and the Clonmacnoise-group. The most striking examples of entries characteristic of 'The Chronicle of Iona' are AU 698.3, a travel entry with expulsio, de regno, and the present passive uechitur, and AU 734.6, which has iuxta, the present passive alligatur, and the partially latinised place name Arx Ollaigh (for Dún Ollaig, modern Dunollie in Argyll). Elsewhere, apud is found in AU 701.8, 710.4, 712.5 (with a Latin personal-name form), and 731.4, a present passive in 734.7, and pergit in AU 699.3.

\footnotetext{
${ }^{120}$ AClon 725.1

121 Immairecc, 'meeting', 'conflict', 'battle', in AU 701.6 and AU 710.4, and distructio, 'a pulling down', 'destruction', in AU 701.8, are found in entries for northern Britain, but they also occur in the Clonmacnoise-group and in entries about Ireland. Immairecc is found in Immairecc Cranchae in both AU 697.6 and AT [697].4, and distructio occurs in AU 676.4, for the destruction of Ailech Frigrenn, which is found as coscradh ('destruction') in AT [676].2 (and mistakenly as coiseacradh, 'consecration', in CS [676].2). These two events took place in Ireland; therefore immairecc and distructio provide extremely weak evidence for a separate style for entries about northern Britain found only in AU.
} 
Battle entries found only in AU also share a number of features with 'The Chronicle of Iona'. AU 727.3, congressio Irrois Foichne, and AU 736.2, the battle of Cnoc Coirpri, both share the use of congressio with other entries from 711 to 737 , including two battle entries in 711 and 719 between the northern Britons and Dál Riata (AU 711.5, AT [711].5; AU 717.5, AT [717].4, CS [717].4, ARC $\left.\S^{*} 170.5\right)$ and battles in Ireland (AU 714.1, AT [714].1; AU 719.5, AT [719].3, CS [719].1). ${ }^{122}$ They also have inter $\mathrm{X}$ et $\mathrm{Y}$, which is typical of battle entries of this period. AU 736.2 shares fugiens, 'fleeing', with only an entry about the defeat of Talorcus filius Congussa by Bruideus filius Oengussa, found in both AU 731.6 and AT [731].5. ${ }^{123}$ In both cases fugiens is used adjectivally with a personal name in the accusative case (Talorcum fugientem in AU 731.6, AT [731].5, and filium Ainfceallaich fugientem in AU 736.2). AU 727.3 has a Latin personal name, Selbachus, and AU 729.2 has iuxta, a partially Latin place-name Stagnum Loogde, inter X et Y; it shares with AU 732.10 (a battle between Cenél Conaill and Cenél Eógain of the northern Uí Néill) the word triumphauit, which is only found in these two entries, and hostis, which is only found elsewhere (as an adjective) in AU 738.4 (the battle of Áth Senaig in Ireland), perhaps meaning 'enemy' rather than 'army'. ${ }^{124}$ All these have features typical of 'The Chronicle of Iona' or found

122 Congressio is found in AU 677.5, AT [677].4, CS [677].4; AU 711.5, AT [711].5; AU 714.1, AT [714].1; AU 717.5, AT [717].4, CS [717].4; AU 719.5, AT [719].3, CS [719].1; AU 727.3; AU 733.3, AT [733].3, AU 734.8; AU 736.2; AU 737.4, AT [737].4; AU 770.8; AU 775.5; AU 780.12; AU 804.7; AU 875.3. The entries on the battle of Áth Senaig (AU 738.4, AT [738].4) have congressi sunt. Congressio introduces battle entries, except in AU 780.12 and AU 804.7, when it refers to ecclesiastical meetings. This and the appearance of a first and second congressio belli in AU 714.1 (AT [714].1) indicates that congressio had a slightly different meaning from bellum, perhaps stressing the coming together of people, either in battle or in a council or synod. Many of the entries shared by AU and the Clonmacnoise-group which have congressio from 711 to 737 also contain stylistic features found in 'The Chronicle of Iona': AU 714.1 (AT [714].1) and AU 733.3 (AT [733].3) have the Latin place-name element campum, AU 719.5 (AT [719].3, CS [719].1) has apud, and AU 737.4 (AT [737].4) has iuxta, the Latin lapis (also found with congressio in AU 717.5, AT [717].4, CS [717].3) for Lia Ailbe and the latinised personal name Cernachus. AU 734.8, describing a battle in Mag nItho in Ulster, has congressio, campum, and natum: the entry is found only in AU and occurs at roughly the same time as the congressio entries for battles in northern Britain which are unique to AU.

123 Also AClon 728.2.

${ }^{124}$ Woolf, 'AU 729.2'. 
in entries shared by $\mathrm{AU}$ and the Clonmacnoise-group, making it unlikely that they come from separate sources.

Two entries unique to AU have unusual vocabulary only found elsewhere in the same contexts in entries of the same period shared by AU and the Clonmacnoise-group. Plural forms of deletus est, 'was destroyed', are used in both the AU-only entry 672.2 (Deleti sunt Ibdig) and the shared entries AU 682.4, AT [682].5 (Orcades deletę sunt la Bruide). Although this verb occurs later in AU 738.4 (AT [738].4), AU 748.3 (AT [748].3), AU 914.4, and AU 943.1, it is found with pene, 'almost', 'nearly', and a word meaning 'all' in every later instance: AU 672.2 and 682.4 (AT [682].5), both about islands of northern Britain, were probably from a single source, perhaps a local written notice. ${ }^{125}$ A similar instance is AU 709.4, Bellum for Orcaibh in quo filius Artablair iacuit. ${ }^{126}$ Iacuit is found elsewhere before 912 only in the shared account two years later of a battle between Picts and the Northumbrians (AU 711.3, AT [711].3) and in AU 852.3. ${ }^{127}$ Again it is likely that both AU 709.4 and the battle-entry for 711 were from the same source which, from the use of apud and the partially Latin place-name Campus Manonn in 711.3, is likely to have been 'The Chronicle of Iona'. In sum, the stylistic evidence indicates that most of the entries for northern Britain found only in AU were part of 'The Chronicle of Ireland' and in many cases 'The Chronicle of Iona', although containing variations in style based on geography, such as the use of deletus est for events in the Orkneys and the Hebrides, may reflect local sources which provided the Iona chroniclers with written notices from other areas.

More evidence that the entries unique to AU were part of 'The Chronicle of Iona' is provided by the subjects of these entries, because they display the same interests as the entries (common to

\footnotetext{
125 deleta est also occurs in FAI $\$ 143$.

126 'A battle won over the Orcadians in which a son of Artablair fell.'

127 The account of the same event in CS [852].3 lacks iacuit.
} 
both AU and the Clonmacnoise-group) which certainly came from that source. These concerns are among those identified by Bannerman as typical of the record for northern Britain: people are captured in AU 673.3, 698.4, and 734.6, are expelled in AU 698.4, travel to Ireland in AU 698.4, 699.3, and 734.7, are drowned in AU 676.3 and 691.5; places are besieged in AU 680.5, 681.5, 683.3, 692.6, 694.4, 703.6, 712.5, and 742.10, burned in AU 698.3 and 712.1, and destroyed in AU 701.9. ${ }^{128}$ While it is possible that a wide range of local chroniclers in northern Britain recorded a broader range of events than their Irish counterparts, the similarity of these interests to those of 'The Chronicle of Iona' must lead to the suspicion that entries concerning northern Britain found only in AU were also part of the same source.

Another reason to doubt Henderson's theory is that entries unique to AU - for events whether in northern Britain or in Ireland - display the same distribution over time. While the correspondence is only approximate, there are very few entries unique to AU for events in northern Britain and Ireland in some sections, as from 660 to 670,685 to 690 and 713 to 718 , whereas, when there are many Irish events found only in AU, there are also more entries for northern Britain unique to AU. ${ }^{129}$

As Isabel Henderson has noticed, the entries for northern Britain unique to AU are often found in medial positions, sometimes in blocks of consecutive entries; but this need not be particularly significant. ${ }^{130}$ When events involving both Britain and Ireland - or events where the

\footnotetext{
${ }^{128}$ For the interests displayed in 'The Chronicle of Iona', see Bannerman, Studies, 15-21; see also above, p. \$\$ (1617). All the obsessio entries after 660 are found only in $\mathrm{AU}$, but there are two earlier shared obsessio entries in AU 626.1 (AT kl 130 [626].5) and AU 638.1 (AT kl 141 [638].1). There is also a unique obsessio entry in AU 641.5, which is highly unlikely to have been part of a 'Chronicle of Applecross', because the event occurred over thirty years before Applecross's foundation. This makes it likely that entries unique to AU after 660 were also part of the 'The Chronicle of Iona'.

${ }^{129}$ See AU 671-6, 691-5, 697-8, 701-2, 709-12. After about 715 there are more Irish entries unique to AU than before; but, although there is a modest increase in the number of entries per decade unique to AU for northern Britain, that increase is not nearly as substantial as for Ireland. From 751 to where AT become lacunose in 766 there are no entries for northern Britain unique to AU.

${ }^{130}$ Henderson, 'North Pictland', 45.
} 
country is uncertain - are not included, $78.7 \%$ of the unique records for northern Britain from 660 to 765 in $\mathrm{AU}$ are found in medial position, none is found in initial position, and $21.3 \%$ occur in final position. ${ }^{131}$ For unique records of Irish events in AU a similar pattern is found: $3.2 \%$ occur in initial position, $67.7 \%$ in medial position and $29.1 \%$ in final position.

Entries unique to $\mathrm{AU}$ about events in northern Britain often are found consecutively, but the same is true for entries describing events in Ireland and unique to AU, which sometimes adjoin the entries unique to $\mathrm{AU}$ about northern Britain. Entries for events in northern Britain and found in both AU and the Clonmacnoise-group occur consecutively in 660, 663, 673, 675, 678, 686, 689, $697,704,713,714,716,717,719,727,731,733$, and 737 . When entries describing events in northern Britain and entries recording events in Ireland and which are unique to AU are taken together, however, they appear consecutively in AU 673.3, 676.2-3, 694.2-5, 695.4-7, 697.4-5, 698.3-6, 699.2-3, 701.4-9, 710.4-6, 725.5-7, 730.4-10, 740.3-5, 741.9-10, 750.6-11. ${ }^{132}$ These consecutive entries, furthermore, tend to be found in medial position. The probable explanation of this pattern is that the entries for northern Britain and Ireland unique to AU were included in AU or omitted from the Clonmacnoise-group chronicle as part of a single process.

The evidence of the entries unique to AU for northern Britain supports Eoin MacNeill's view that events in northern Britain, earthquakes, and people of minor interest were generally omitted by a redactor of the Clonmacnoise-group. ${ }^{133}$ The entries for northern Britain may have been disproportionately omitted because the people and places there were less well known in Ireland

\footnotetext{
${ }^{131}$ Note that groups of events at the start or end of an annal are all counted as being in initial or final position.

${ }^{132}$ Sometimes, entries for northern Britain unique to AU do not occur in such blocks, even when there are other entries unique to $\mathrm{AU}$ in the same annal. Quite often the same pattern is found for the unique Irish entries (see AU 671.2 and 671.4, 675.2 and 675.5, 697.4-8 and 697.11-12, 719.1-4, 719.8 and 719.10; 721.2 and 721.4-5; 722.2 and 722.7).

${ }^{133}$ Mac Neill, 'The authorship', 74, 85. See also Evans, The Present, 201-4. Nonetheless, the broader issue of entries unique to AU requires further study.
} 
and were often not explicitly identified. ${ }^{134}$ It is difficult to explain the entries unique to AU for northern Britain independently of those found only in AU for Ireland. In addition, the same style and subject-matter are shared by the record for northern Britain unique to AU and the corpus of entries about northern Britain common to $\mathrm{AU}$ and the Clonmacnoise-group, which (I have argued) ${ }^{135}$ was produced in Iona. This makes it highly likely that most entries for northern Britain found only in AU were part of 'The Chronicle of Iona' rather than a 'Chronicle of Applecross'.

\section{Clonmacnoise-group entries not found in $A U$}

There are also entries concerning northern Britain found only in the Clonmacnoise-group, mostly in the period from 724 to 733 . David Dumville has discussed the large number of differences between AU and the fragment of AT covering the years from the late fifth century to 766, including the existence of 277 entries unique to AT and extra details in Clonmacnoise-group versions of entries which are also in AU. ${ }^{136}$ Many of these extra entries were included from other sources, notably Bede's Chronica maiora and lists of kings of Irish provinces and of Ireland. ${ }^{137}$ This took place at some point between 911, when the common source of AU and the Clonmacnoise-group ended, and about 1092, when 'The Annals of Inisfallen', which contain some of the additional Clonmacnoise-group entries, were written. Events in northern Britain could also have been included in this period; but, while the record of the kings of Dál Riata before 642 was probably altered and supplemented from king-lists and perhaps other sources, these changes were undertaken in a less systematic manner than for the major Irish overkingships; therefore it is

\footnotetext{
${ }^{134}$ Entries for both Britain and Ireland, which describe natural phenomena, plagues, and famines and entries with only a personal or place-name following obsessio, combustio, and bellum also tend to be lacking from AT and CS.

135 See above, pp. $\$ \$ \$-\$ \$$.

136 [Grabowski and] Dumville, Chronicles, 112.

${ }^{137}$ Ibid., 112-15; Evans, The Present, 189-224.
} 
unclear whether the record of events in northern Britain was altered in the same way as Ireland's record. ${ }^{138}$

While certainty regarding the source of any given entry unique to the Clonmacnoise-group is often not possible, stylistic features and the position(s) of these entries in the annal can provide strong indications. Most of the Clonmacnoise-group entries unique to that source are found in batches at the end of an annal. Therefore, those few unique entries about northern Britain in the middle of an annal are more likely to have come from 'The Chronicle of Ireland'; this is especially so when they are surrounded by shared entries about events in northern Britain. ${ }^{139}$ When all these aspects are studied, they indicate that most of the entries unique to the Clonmacnoise-group concerning events in northern Britain were probably derived from 'The Chronicle of Ireland' and were lost at some point after 911 during the transmission of the text ancestral to AU.

There are five ecclesiastical entries from the period 660-800 found only in the Clonmacnoisegroup.

AT [661].4 (CS [661].4): ${ }^{140}$ Cumíne abas ad Hiberniam uenit.

AT [715].8: Dorbéne abb Ię.

AT [718].6 (CS [718].3): ${ }^{141}$ Tonsura corona super famil<i>am Iae datur.

AT [726].2: ${ }^{142}$ Cillenus Longus ab Iae pausad.

AT [758].2: ${ }^{143}$ Reuersio Slébíne in Ibernia.

\footnotetext{
${ }^{138}$ Ibid., 208-13.

${ }^{139}$ For the location of entries unique to the Clonmacnoise-group, see [Grabowski and] Dumville, Chronicles, 119.

${ }^{140}$ ARC $\$ 130.3$, AClon 657.3.

${ }^{141}$ ARC $\$ 171.4$.

${ }^{142}$ ARC $\S * 176.3$, FAI $\S 190$, AFM 725.3.

${ }^{143}$ ARC $\$ 191.3$.
} 
Marjorie Anderson suggested that these entries - all of which concern Iona - were from a chronicle kept at an Irish Columban centre, because she considered that uenit in AT [661].4 (CS [661].4) indicated that the entry was written in Ireland. ${ }^{144}$ None of these entries would be out of place in a 'Chronicle of Iona'. The entry on the change in tonsure by the Ionan familia reflects the same interest displayed in AU 716.4 (AT [716].3), which describes the changing of Easter in Iona, and AT [718].6 (CS [718].3) has the present passive datur, 'is given', 'is permitted'. The two travel entries, AT [661].4 (CS [661].4) and AT [758].2, need not have been written in Ireland; uenit does not necessarily indicate movement towards the writer, and the preposition in AT 758.2 might originally have been $d e{ }^{145}$ Sléibéne's travel entry is found in the middle of the annal in AT, whereas two other entries unique to AT are at the end of the same annal, a distribution which increases the probability that AT [758].2 derives from 'The Chronicle of Ireland'.

AT [715].8, the only item unique to that text in the annal, occurs in final position. This, the fact that there is an item in AU 713.5 (AT [713].5) recording the succession of Dorbéne to the kathedra of Iona and his subsequent death after five months in primatu, and that there is no other evidence that another Dorbéne succeeded him, makes it likely that the item in AT is a late addition. ${ }^{146}$ The lack of vocabulary explaining the event makes it particularly difficult to analyse, so it is unclear whether it was derived from another source or was created because the interpolator only noticed the succession part of the pre-exiting item but not the obituary statement.

The obit for Cilléne longus, abbot of Iona, in AT [726].2, also appears two years after his succession item in AU 724.1 (AT [724].1), and does not contain any details, such as a patronymic,

\footnotetext{
144 Anderson, Kings, 37-8. Note that Anderson did not include the AT [715].8 item, which is not found in Stokes's edition.

145 The amendment to de, proposed by Marjorie Anderson (ibid., 8, n. 32), is supported by the appearance of $d e$ in the equivalent entry in ARC \$191.3. See above, pp. \$\$-\$\$ (8-11), for a discussion of travel entries.

${ }^{146}$ Herbert, Iona, 58-9.
} 
not found in the earlier item, so on the face of it the situation is similar to that for the item unique to AT concerning Dorbéne. However, the use of pausare, 'to rest (in the grave)', is found on a number of occasions for people associated with Iona, although it is also attested for other ecclesiastics. ${ }^{147}$ In AT Cilléne's obit immediately follows the entry on the binding of Nechtan son of Derilei by Drust, king of the Picts, found in both AU and the Clonmacnoise-group; it does not adjoin the two events unique to AT recorded at the end of the annal. It is quite likely that a Cilléne was abbot of Iona before Cilléne Droichtech, who may already have held a prominent position in the Iona community by $727 .{ }^{148}$ Therefore, the item for Cilléne longus is, unlike the unique item for Dorbéne in AT, likely to be correct historically, and its vocabulary and position indicates that it was derived from 'The Chronicle of Iona'.

Overall, most of these ecclesiastical entries correspond with the style and interests of 'The Chronicle of Iona', and their positions are sometimes not the same as other entries likely to have been Clonmacnoise-group additions, which makes it probable that these entries derive from 'The Chronicle of Iona', via 'The Chronicle of Ireland'.

There are eleven secular entries found only in the Clonmacnoise-group from 660 to 766 , after which both AT and CS are lacunose. ${ }^{149}$

AT [724].2: ${ }^{150}$ Clericatum [N] eactain reigis Pictorum. Druxst post eam regnat.

AT [726].4: Dúngal de reghno iectus est et Druist de reghno Pictorum iectus et Elphin pro eo regnat. AT [726].9: ${ }^{151}$ Eochaid mac Eachach regnaire incipit.

\footnotetext{
${ }^{147}$ See above p. $\$ \$$ (7), n. 39.

${ }^{148}$ On the appearance of two people called Killeni in the Salzburg list of Iona abbots, and on the career of Cilléne Droichtech, see Herbert, Iona, 60-1.

${ }^{149}$ In the section from 741 to 800 there are no other entries for northern Britain in AI, ARC, FAI, AClon or AFM which are not found in AU, apart from AFM 754.4, an obituary notice of an abbot of Iona.

${ }^{150}$ AClon 722.2.

${ }^{151}$ ARC $\S * 176.2$.
} 
AT [729].2: Trí .l. long Picardach do brisidh ir Ross Cuissine sa bliadain cétna.

AT [732].7: ${ }^{152}$ Nechtan mac Derile moritur.

AT [733].4: ${ }^{153}$ Flaithbertach clasem Dal Riada in Iberniam duxit et ceades magna facta est de $\langle e\rangle$ is in insola hOine uibi hi trucidantur uiri: Concobar mac Lochéni et Branchú mac Brain et multi in flumine demersi sunt in Banna.

AT [733].5: Eochaid mac Echach rí Dail Riada et Conall mac Concobar mortui sunt.

AT [752].2: Taudar mac Bile rí Alochlandaib <from Rí Alo Cluaithe>. ${ }^{154}$

AT [752].5: Cath Asreith in terra Circin inter Pictones inuicem, in quo cecidit Bruidhi mac Maelchon.

AT [759].7: ${ }^{155}$ Aengus rí Alban moritur.

AT [764].12: ${ }^{156}$ Moll rí Saxan clericus eficitur.

Marjorie Anderson proposed that the entries concerning kings of Dál Riata and kings of Picts in this group probably came from king-lists because they were unlikely to have been omitted during the later prehistory of AU. ${ }^{157}$ When these entries are analysed in detail, however, it becomes clear that many could have been part of 'The Chronicle of Iona'.

The only certain addition to the Clonmacnoise-group in the section from 660 to 800 is the inclusion of a duplicate obit for the Pictish king Unuist son of Uurguist at AT [759].7. ${ }^{158}$ The entry from 'The Chronicle of Ireland' for the same event is found two years later at AT [761].4 (Aengus mac Fergusa regis Pictorum moritur) and AU 761.4. It is striking that 'The Annals of Roscrea'

\footnotetext{
152 AClon 729.6.

${ }^{153}$ FAI $\$ 221$, AClon 730.1.

154 rí Alochlandaib seems to be a reinterpretation of the original text as rí a Lochlandaib, 'king among the Lochlannaig', referring to the Vikings (perhaps more specifically Norway).

${ }^{155}$ AClon 755.1 and 757.1.

${ }^{156}$ ARC §*195.3, AClon 759.7.

157 Anderson, Kings, 35.

${ }^{158}$ Evans, The Present, 209-10.
} 
also have an extra entry in the 770s for the Pictish king Ciniod son of Uuredech, who ruled from 763 to 775 , in the period when AT and CS are lacunose. ARC $\S * 203.5$ (Cinaeda m. Alpin ríg Alban), like the duplicate for Unuist, is found before an entry for the same king at ARC $\S * 205.3$ (Mors Cinaedon regis Pictorum), in positions which correspond respectively with AU 773 and the item for Ciniod at AU 775.1. ${ }^{159}$ The inclusion of m. Alpin in ARC $\S * 203.5$ probably resulted from a confusion with the later Cináed mac Alpin, king of Picts, who died in $858 .{ }^{160}$ The position of the item in ARC $\S * 203.5$ before the pre-existing item and its anachronistic use of rí Alban indicates that it was included at the same time as AT [759].7, although a study of ARC needs to be undertaken before this can be verified.

The source of these entries could have been another chronicle which lacked two annals before 761, or a king-list, perhaps of Alba, although only the Pictish king-lists include Unuist son of Uurguist and Ciniod son of Uuredech. A king-list of Alba including these Pictish kings is not extant, but it is possible that after the gaelicisation of the Pictish provinces a number of people would still have wanted to include Pictish kings in their king-lists, perhaps because of their prestige and these kings' links with ecclesiastical establishments. The use of rí Alban and Albanaig is also found in Clonmacnoise-group additions to earlier items, seemingly relating to Dál Riata in distinction to Cruithni, which was used as the translation of Picti ${ }^{161}$ This makes it possible that the king-list of Alba made some Pictish kings of the eighth century the successors of kings of Dál Riata, which would be understandable since the Pictish king Unuist son of Uurguist (732-61) conquered Dál Riata and the creation of Alba later, by the late tenth century, came to be depicted

\footnotetext{
159 Jaski and Mc Carthy, A facsimile, 51, identifies $\$ 204$ as the later work of O'Sheerin. The items immediately before ARC $\S * 203.5$ occur in AU 773, and those preceding ARC $\S * 205.3$ are found in AU 775.

${ }^{160}$ The obit of Ciniod son of Alpin is found in AU 858.2, AI [858].3, Annales Cambriae versions A and B 858.1, Annales Cambriae, A.D. 682-954: Texts A-C in Parallel, ed. and trans. David N. Dumville (Cambridge, 2000), 1213; for FAI §285, see Fragmentary Annals of Ireland, ed. and trans. Joan Newton Radner (Dublin, 1978), 112.

${ }^{161}$ See Evans, The Present, 208-10.
} 
as a takeover of the Picts by Dál Riata. ${ }^{162}$ The usage of Alba terminology in the Clonmacnoisegroup probably reflects one late attempt to reconcile this contradictory evidence, possibly using the Pictish king-lists for the eighth-century kings. ${ }^{163}$

There are indications nevertheless that other entries on kings of the Picts and kings of Dál Riata were not included from secondary sources. The obit for Nechtan son of Derilei (AT [732].7) lacks the title rí Alban found with the other unique Clonmacnoise-group obits. Most of the secular obits unique to AT (apart from 'kings of Ireland' and Byzantine emperors), many of which derive from king-lists, give the subjects a title, whereas the Pictish kings in 'The Chronicle of Ireland' often have none. ${ }^{164}$ In addition, none of the surviving Pictish king-lists specifies whether people were deposed or how long they lived afterwards, perhaps because it would weaken the image of stable continuity which such a king-list might be designed to project. Another reason to doubt that it was an addition is that Nechtan's obit is the seventh out of twelve events recorded in AT 732, not in final position where most of the extra text in the Clonmacnoise-group is found. ${ }^{165}$

162 Dauvit Broun, 'Alba: Pictish homeland or Irish offshoot?', in Exile and Homecoming. Papers from the Fifth Australian Conference of Celtic Studies, University of Sydney, July 2004, ed. Pamela O'Neill (Sydney, 2005), 23475 , at $263-6$.

163 The fourteen years between the obits of Unuist and Ciniod in the Clonmacnoise-group texts agrees with both the AU annal-interval and the Series longior 1 Pictish king-list, which probably retains the reign-length of the early kinglist accurately (Series longior 2 has 27 years and this section of the Series breuior group of Pictish king-lists is extremely confused, owing to the movement of names and its compilation from two king-lists). For these designations see M. Miller, 'The disputed historical horizon of the Pictish king-lists', Scottish Historical Review 58 [1979], 1-34, at 1, n. 2, 2(-3), n. 3. See also Anderson, Kings, 77, and for editions of individual versions, see ibid., 245-9, 261-89. The reign of Unuist son of Uurguist can be calculated either from the Pictish civil war in 728-9 (which possibly began in 724), in which he rose to prominence, or from the obit (unique to the Clonmacnoise-group) of Nechtan son of Derilei (AT [732].7), who had previously been a king of the Picts (see Woolf, 'AU 729.2', ). Counting from the civil war to his obit, the annal-interval for Unuist's reign is thirty years, while from Nechtan's obit to Unuist's there are 27 years. In Series longior Unuist has a reign of thirty years, whereas in Series breuior he probably originally had 26 or 36 years: therefore if the end of the civil war were taken as the starting point of Unuist's reign, then the obit for Unuist unique to the Clonmacnoise-group could have come from a Series longior list; but if Nechtan's obit were the starting point, then a Series breuior list could have been used, if Series breuior originally had 27 years for Unuist. Overall, while it is uncertain what source was used, it could have been related to the Pictish king-lists.

${ }^{164}$ See Grabowski and Dumville, Chronicles, 128-37.

${ }^{165}$ It is the only event in AT's annal which is not also present in AU 732. 
AT [724].2 and AT [726].4, both describing changeovers in the kingships of Dál Riata and the Picts, have similar final clauses (post eam [!] regnat in AT [724].2 and pro eo regant, corrupted from regnat, in AT [726].4) which indicate that they come from a single source. AT [726].4 is found in an annal which also has two events unique to AT recorded in final position, but it occurs in medial position in the annal, not adjacent to these other unique items. The use of de regno, found in AT [726].4, is a feature of 'The Chronicle of Iona'. ${ }^{166}$ AT [724].2, the sole entry unique to AT in that annal, is also in medial position, following an entry shared by AU and AT (AU 724.1, AT [724].1) on the death of Fáelchú mac Dorbéni, abbot of Iona, and the succession of Cilléne longus to the principatus of Iona. Overall, these are indicators which point to 'The Chronicle of Ireland' as the source for these two entries as well as the obit of Nechtan, and there is no evidence that they were later additions.

The sources of the subsequent notices of events in the kingship of Dál Riata - the succession of Eochaid mac Echach (AT [726].9) and his obit (AT [733].5) - are difficult to identify through their vocabulary. ${ }^{167}$ AT [726].9, preceded by another entry not present in AU, occurs at the end of the annal, like many of the entries unique to the Clonmacnoise-group; therefore, especially given the use of a Dál Riata king-list for additions to earlier sections, it is possible that this entry is an addition made after 911 in the common source of the Clonmacnoise-group. ${ }^{168}$ However, the obit

\footnotetext{
${ }^{166}$ For de regno see above, pp. \$\$ \$ \$ (11-12).

${ }^{167}$ Regnare incipit does not provide conclusive evidence; it is found in the entries from 'The Chronicle of Ireland' (for example, AU 643.5, CS [643].5; AU 672.5, AT [672].4, CS [672].3; AU 675.6, AT [675].2, CS [675].2; AU 696.7) and in Clonmacnoise-group additions, as well as in entries in the Clonmacnoise-group after 911 (CS [916].6; AT [980].2, CS [980].2; CS [1001].6 where AT [1000].7 has regnat). All of these instances are for the overkingship of Uí Néill; succession entries for other kingships were rare in the 'The Chronicle of Ireland', but AU 733.2, AT [733].2, has regnum generis Loairnd assumit; and the Clonmacnoise-group additions for provincial kings in Ireland sometimes have regnat and regnauit (from regnare, 'to reign', 'to rule'), rexit (from regere, 'to rule'), cui successit, 'to whom succeeded', $\mathrm{X}$ i ríghi $\mathrm{Y}$, ' $\mathrm{X}$ (was) in the kingship of $\mathrm{Y}$ ', $\mathrm{X}$ do gabáil ríghi $\mathrm{Y}$, ' $\mathrm{X}$ held the kingship of $\mathrm{Y}$ ', and often there is no formula at all, just a name and title. However, regnare incipit is not found; therefore, the use of this formula in AT [726].9 for Eochaid mac Echach, a king of Dál Riata, is somewhat anomalous.

${ }^{168}$ Evans, The Present, 210-13.
} 
of Eochaid in AT [733].5 is found in the middle of the annal, preceded and followed by entries shared by AU and AT and therefore from 'The Chronicle of Ireland'; it is immediately preceded by another entry unique to AT on Flaithbertach mac Loingsig, king of Cenél Conaill, leading the fleet of Dál Riata to defeat in Ireland, and it is accompanied in [733].5 by the obit of Conall mac Conchobuir. The evidence for these items is overall inconclusive.

The sources of the obit of Taudar mac Bile, king of Dumbarton (AT [752].2), the entry on the battle of Asreth (AT [752].5), and the entry on King Æthelwold Moll entering religious life (AT [764].12) are not clearly identifiable, although they would not be out of place in 'The Chronicle of Ireland'. Rí Alo Cluaithe in AT [752].2 is found elsewhere in Irish chronicles (with rex) as the title for the kings of Dumbarton. ${ }^{169}$ It was proposed by O'Rahilly and Anderson that the notice of the battle of Asreth was misplaced from the reign of Bridei son of Maelchon in the late sixth century, due to the use of 84 -year Easter cycles. ${ }^{170}$ Dumville has questioned this theory, suggesting that this item, albeit perhaps supplemented by Clonmacnoise-group additions, would fit the political context of the reign of Unuist son of Uurguist in the mid-eighth century. ${ }^{171}$ This view is supported by other evidence. Inter $X$ et $Y$ or inter $X$ inuicem in this entry is found twenty-six times in AU from 730 to 770, but only once near the late sixth century, at AU 603.2 (AT kl 109 [603].2), ${ }^{172}$ which might be the result of rewriting in the eighth century. ${ }^{173}$ This formula and in quo cecidit

\footnotetext{
${ }^{169}$ See AU 658.2; AU 694.6, AT [694].2, ARC §154.2; AU 722.3, AT [722].3.

${ }^{170}$ O'Rahilly, Early Irish History and Mythology, 508, Anderson, Kings, 36-7.

${ }^{171}$ Grabowski and Dumville, Chronicles, 124-7. Dumville has suggested that in quo cecidit Bruidhi mac Maelchon, or just the patronymic, could have been added. The latter proposal finds support in the erroneous appearance of mac Alpin for Ciniod son of Uuredech in ARC $\$ * 203.5$.

172 AFM 598.3.

${ }^{173} \mathrm{AU}$ 603.2 have in fugam uersus est, 'was turned into flight'; AT kl 109 [603].2 have in fugam euersus est. Euersus est ('was overtaken', 'was overturned') is unique to the AT entry, but uersus est is found elsewhere, occurring with in fugam in CS [638].1 on the Battle of Glenn Mairison; AU 765.5, AT [765].6; AU 787.3. In fugam uersa est in CS [638].1 is not found in other chronicles' entries on the battle of Glenn Mairison (although the equivalent item at AT kl 141 [638].1 has do teicedh, 'fled'), making it possible that in fugam uersa est was not in 'The Chronicle of Ireland'. While the evidence is not conclusive, the formulae in fugam uersus est, and inter $\mathrm{X}$ et $\mathrm{Y}$ do not appear elsewhere in the annals around 600 but are used in the late eighth century, making it likely that AU 603.2 (AT kl 109 [603].2) was rewritten or created in the latter period.
} 
occur in AU 750.4 (AT [750].4), in a battle between the Picts and the Britons two annals before 752. ${ }^{174}$ The two entries unique to AT in the annal for 752 are found adjacent to the obits of Cilléne anchorite of Iona and Cumméne ua Bécce, relegiosus of Eigg, and separate from the other ATonly entry at the end of the annal. Therefore, the entry about the battle of Asreth, in terms of its position and vocabulary, corresponds with the other entries for northern Britain in the mid-eighth century. The last entry for an event in northern Britain unique to AT is AT [764].12, on Æthelwold Moll, king of the Northumbrians, entering into religious life. It has a present passive, eficitur, which is a feature of 'The Chronicle of Iona', but it is found in final position, where the majority of the entries unique to AT occur; so there is no conclusive evidence for its source, but the evidence of vocabulary is perhaps more significant than the item's position. ${ }^{175}$ These three entries, AT [752].2, [752].5, and [764].12, are likely to have been part of 'The Chronicle of Ireland' and derived from contemporary accounts, although their ultimate sources from northern Britain are uncertain.

Overall, most of the entries unique to AT could have been in 'The Chronicle of Ireland' and before 740 probably also in 'The Chronicle of Iona', although a few may have come from other sources, perhaps chronicles or king-lists. After 740, although the situation is less certain, it is likely that most were derived from 'The Chronicle of Ireland'.

\section{Other Possible Chronicle Sources for Northern Britain}

The preceding discussion indicates that relatively few items for events in northern Britain to 800 were entered after 911 into the Irish chronicles, but it is still possible that sources from northern

\footnotetext{
${ }^{174}$ In AU 750.4 (AT [750].4 has been translated into Gaelic). The word terra, found in this entry, is rare, elsewhere occurring before 1100 only in AU 804.11.

175 Grabowski and Dumville, Chronicles, 115, n. 20.
} 
Britain other than a 'Chronicle of Iona' were included in 'The Chronicle of Ireland'. That entries from other chronicles were in fact added already by 911 is indicated by duplicates which are grossly out of place in both AU and the Clonmacnoise-group. In the annals for the seventh century the entry for the battle of Glenn Mairison (in which Domnall Brecc, king of Dál Riata, died) occurs in both AU 642.1 (AT kl 144 [642].2, CS [642].1) ${ }^{176}$ and, much later, in AU 686.2 (AT [686].6, CS [686].1). ${ }^{177}$ The contents of two more items - one on the battle of Calathros in AU 678.7 (AT [678].8), ${ }^{178}$ which also involved Domnall Brecc, and an obit for Ferchar mac Conaill Chirr in AU 694.5 - fit a mid-seventh-century context, indicating that they share the same displacement, but there is no surviving item marking these items' original locations. ${ }^{179}$ The obituary notice of Talorgg son of Acithaen in AU 686.2 (AT [686].5), which immediately precedes the battle of Glenn Mairison item, and the obituary item for Tomnat wife of Ferchar in AU 695.6 (if the husband is the Ferchar of AU 694.5 rather than the Ferchar Fota whose death is recorded in AU 697.2) may also be out of place due to the same error. ${ }^{180} \mathrm{~T}$. F. O'Rahilly argued that these displacements were caused by the use of 84-year-cycle paschal tables with entries in their margins, but this is uncertain. ${ }^{181}$ The source of these entries is not clear, although the duplicate of the battle of Glenn Mairison could indicate that it was another version of 'The Chronicle of Iona'. The existence of these misplaced entries does demonstrate a continued interest in Dál Riata on the part of Irish chroniclers after 740, and the continued availability of a text of 'The Chronicle of Iona'.

\footnotetext{
${ }^{176}$ ARC $\$ * 116.4$.

177 Anderson, Kings, 30-1.

${ }^{178}$ AClon 674.6.

179 Anderson, Kings, 30-1, 110-11.

${ }^{180} \mathrm{Ibid}$., 30-1, 110-11. Another, unrelated, duplication could be the two obits for Dairgart son of Findguine in AU 686.3, AT [686].7, CS [686].3, and AU 693.6.

${ }^{181}$ O’Rahilly, Early Irish History and Mythology, 257.
} 
Both Kathleen Hughes and Isabel Henderson argued that sources from Pictland, as well as these misplaced entries, could have found their way into Irish chronicles. ${ }^{182}$ There are certainly many entries on Pictish affairs after about 710, and, whereas secular events in Dál Riata are rarely found, after 740 Pictish events continue to be noted. The Pictish civil war of $728-9$ (perhaps beginning in 724) and the subsequent military activities of Unuist son of Uurguist in the 730s in particular are recorded in unusual detail; this led both Hughes and Henderson to propose that a Pictish narrative underlay the chronicle account. While the evidence for the period after 740 will be dealt with below, the style of many Pictish entries before 740 corresponds with that of 'The Chronicle of Iona' and, after 740, with the vocabulary of Irish events. Before 740, Pictish entries often have apud, present passives, and iuxta. Rex without the kingship being stated, while found only for kings of Picts, occurs in combination with other vocabulary of 'The Chronicle of Iona' in the 710s and 720s. The close interest in Pictish affairs in the 730s is very understandable because in that decade the Pictish king Unuist son of Uurguist undertook repeated campaigns in Dál Riata. The earlier attention to the Pictish civil war of 728-9 (perhaps 724-9) could also be explained by the importance for Iona of maintaining good relations with the Pictish king; familia Iae had been expelled from Pictland by King Nechtan in $717 .^{183}$

'The Chronicle of Iona' can largely account for the Pictish record before 740, but, given the level of detail in some of these entries - for example, the entries for the battle of Dún Nechtain in 685 and the civil war in 728 and 729 -, it is likely that written information was reaching the Ionan chroniclers from Pictland, perhaps in the form of written notices from other chroniclers. While most of the Pictish entries are written in the normal style of 'The Chronicle of Iona', it is possible that elements from these Pictish sources remain.

\footnotetext{
182 Hughes, Celtic Britain, 97-8; Henderson, The Picts, 167-8. See also Fraser, From Caledonia, 372.

${ }^{183}$ AU 717.4, AT [717].3, CS [717].2.
} 
After 740, the stylistic evidence is very slim, consisting of obits, four battles, the 'smiting' of Dál Riata by Unuist son of Uurguist in AU 741.10, and the 'ebbing' of the sovereignty of Unuist in AU 750.11. The obits are similar to contemporary Irish entries, but they do not give sufficient detail to enable us to identify their sources. The battle entries are all also relatively typical of the Irish entries of the same time, introducing the participants with inter or the Gaelic equivalent iter. ${ }^{184} \mathrm{AU} 789.11$, the first of two entries on the battle between Constantin son of Uurguist and Conall son of Tadc, also has uictus est and euassit, which are found in notices of Irish battles of the same period. ${ }^{185}$ The entries on the 'smiting' of Dál Riata and the 'ebbing' of Unuist's sovereignty are unusual in both vocabulary and content, but they are too brief to allow identification of their sources. ${ }^{186}$ A degree of familiarity with Unuist is also found in AU 750.4, which describes Talorggan son of Forggus as frater Oengussa, the brother of Unuist son of Uurguist, king of Picts. These entries could be used as evidence for a Pictish source, but it should be remembered that 'The Chronicle of Iona' similarly referred to Unuist without giving his patronymic. ${ }^{187}$ The evidence - that these entries sometimes have stylistic features characteristic of contemporary records of Irish events but also content unique to entries for northern Britain and

\footnotetext{
${ }^{184}$ AU 750.4, AT [750].5; AT [752].5; AU 768.7; AU 789.11, duplicated at AU 790.7.

${ }^{185}$ In the second half of the eighth century uictus est is also found in AU 784.7, 787.4, and 789.16, and euassit in AU 769.1, 789.12, 789.16, 796.6. Uictus est is also found in the late sixth and seventh centuries and in AU 746.4, but it is not found from 800 to 1200, except in AT [1156].5. Euassit is very rare before 700 but then becomes quite common from 735 to the mid-ninth century (occurring twelve times from 735 to 852), after which it is only found in AU 897.2, CS [897].1; AU 914.3, AU 937.6, AT [995].2, AT [1156].5; therefore the combination of uictus est and euassit in the Pictish battle in AU 789.11 is likely to have been written by a contemporary chronicler in Ireland, rather than by a later writer.

186 The fact that AU 750.11 is in Gaelic does not necessarily preclude the possibility of a Pictish writer of this entry. As Charles-Edwards (The Chronicle of Ireland, I, 24) argues, the use of Gaelic does not necessarily indicate that an item was not contemporary in this period.

${ }^{187}$ See AU 729.2; 729.3, AT [729].4; AU 731.6, AT [731].5; AU 734.7. The equivalent entry for AU 750.4, at AT [750].5, has the entry in Gaelic, but it mistakenly states that Talorgan's brother (the name Óengus is not given) died as well.
} 
unusual features - perhaps indicates that most of the Pictish entries after 740 were derived from one or more written sources from northern Britain, which were then included, sometimes after being rewritten, in a chronicle in Ireland.

Other features of the record after 740 could support a theory that two sources from northern Britain were used. Entries for events in northern Britain after 740 are often found in two different positions in an annal. For example, events involving people from northern Britain are found in: AU 747.5 (AT [747].6), ${ }^{188}$ the death of Cú Chuimne sapiens, and 747.10 (AT [747].11), the obituary notice of Tuathalán, abbot of Cennrígmonaid (St Andrews); AU 750.4 (AT [750].5), ${ }^{189}$ the Battle of Catohic between the Picts and Britons, and AU 750.11, 'The ebbing of the lordship of Óengus'; the obits of Cilléne Droichtech in AU 752.1 (AT [752].1), ${ }^{190}$ Cumméne ua Bécce, religiosus of Eigg in AU 752.2 (AT [752].2) but Cilléne son of Congal on Iona in AU 752.8 (AT [752].11); AU 778.7, ${ }^{191}$ the death of Áed Finn son of Eochaid, king of Dál Riata, and perhaps the obit of Eithne daughter of Cináed (if he was the king of the Picts who died in 775) at 778.11; ${ }^{192}$ and AU 780.1, the burning of Dumbarton Rock, separated from 780.5, ${ }^{193}$ the death of the Pictish king Elpin. AU 790.1, ${ }^{194}$ on the death of Noe, abbot of Kingarth, appears in the same annal as an item of Pictish battle between Conall son of Tadc and Constantin son of Uurguist at 790.7. However, the latter item is also found in AU at 789.11 in a fuller version, and, as AT and CS are lacunose in this period, it is uncertain when this duplication took place. ${ }^{195}$ The pattern of items for

\footnotetext{
${ }^{188}$ AI 747.3, AFM 742.7.

189 AClon 746.2.

190 AFM 747.2.

${ }^{191}$ AClon 769.4.

192 AFM 773.7.

193 ARC $\S * 211.2$, AClon 773.1.

194 AFM 785.2

195 'The Annals of Roscrea' are also lacunose between 782 and 802, and this battle is not found in AI, AFM, AClon or AB. As Charles-Edwards (The Chronicle of Ireland, I, 22) states, the duplicate items for the battle between Constantín and Conall indicated the usage of different chronicles.
} 
northern Britain in different positions in the annal could have resulted from the use of two separate sources, but, equally, information about events in northern Britain could have reached chroniclers more than once a year; so the two-source hypothesis would be a risky inference if applied to all such events. Given that only the two more uncertain items at AU 778.11 and 790.7 are found in final position, it is unlikely that this was a result of some items being added retrospectively; rather, they were included when the annals were first written in Ireland.

Since, as has been discussed above, after 740 Iona remains a prominent feature of the record for northern Britain, and 'The Iona Chronicle' before 741 displayed a strong interest in Pictish affairs, it is likely that a continuation of this source can account for some of the Pictish items after 740. However, there is some evidence for a more Pictish perspective. One is the existence of the obit for Tuathalán, abbot of Cennrígmonaid (St Andrews) in AU 747.10 (AT [747].11), ${ }^{196}$ which is the first occasion when a Pictish ecclesiastical centre east of Druim Alban is named. There is also the record of the death of Dub Tholargg, rex Pictorum citra Monoth ('king of the Picts this side of Monoth') in AU 782.1. In combination, these have been used to argue that a Pictish source was kept at St Andrews, partly because Monoth has been equated with the Mounth and citra Monoth taken to indicate a southern viewpoint. ${ }^{197}$ While AU 782.1 does indicate the viewpoint of someone in northern Britain, it is not made clear where Monoth refers to, and from what side of Monoth the account was written, although it is unlikely to have been in Fortriu. ${ }^{198}$ The appearance

\footnotetext{
196 AFM 742.8.

${ }^{197}$ Hughes, Celtic Britain, 97-8; Fraser, From Pictland, 327-8, 371.

198 Simon Taylor, 'Pictish Place-names Revisited' in Pictish Progress. New Studies on Northern Britain in the Early Middle Ages, ed. Stephen T. Driscoll, Jane Geddes, and Mark A. Hall (Leiden, 2011), 67-118, at 103, states that there are scarcely any cases of the element 'north or west of the Great Glen', which increases the probability that the Mounth separating northern and southern Pictland was intended in the Irish chronicle item, but Watson, The History, 406-7, gives a few examples of monadh as a mountain range in Argyll, the Isles, and the use of 'the Mounth' or 'the Mound', as an old name for the Ord of Caithness. It is unclear whether the fact that Dub Tholargg's name is followed immediately by that of an equonimus of Iona, Muiredach mac Huargaile, should be regarded as significant, indicating a western perspective.
} 
of AU 782.1 is the only instance before 1100 in AU, AT, and CS where the geographical extent of a kingship is described, and the lack of a specific element in the place-name indicates that monadh in this instance refers to a significant geographical marker. Given that Fortriu was the main focus of power in northern Pictland, it is unlikely that a chronicler based there would have needed the more descriptive citra Monoth to describe that region. It is tempting to identify Monoth with the Mounth, the range of mountains dividing Speyside and Deeside from Strathmore and Atholl, but a viewpoint from the western seaboard, where there were also Picts, cannot be completely ruled out, even if an obit of Fergus mac Echach, king of Dál Riata, found at AU 781.3 in the previous year, reduces the chance that Dub Tholarrg ruled in the west. ${ }^{199}$ Moreover, Ionan sources, including a 'Chronicle of Iona' item in AU 717.4 (AT [717].5, CS [717].2) and Adomnán's 'Life of St Columba', contain a different method of referring to the geography of northern Britain, using dorsum Brittanniae, 'the ridge of Britain', the Latin equivalent to the later Gaelic Druim Alban, for the watershed dividing Britain east from west north of Clyde, thus separating Argyll and the western seaboard from the Pictish lands to the east. ${ }^{200}$ When combined with the St Andrews item, it is therefore probable, but by no means certain, that southern Pictland in addition to Iona provided news for Irish chroniclers in this period. Whether or not this is correct, the position of the records for northern Britain, as well as the presence of Irish stylistic features, indicates that after 740 written notices from northern Britain went to Ireland very soon after the events recorded took place, before being rewritten by Irish chroniclers, and then included in the first manuscript version of each annal.

\footnotetext{
${ }^{199}$ Fergus's obituary notice also appears at AClon 778.2, AFM 776.7. See Fraser, From Caledonia, 327-8, for the view that the item, written from a southern perspective, is part of the evidence for a division of the Pictish kingdom with the Mounth as the border.

${ }^{200}$ Dunshea, 'Druim Alban, Dorsum Brittanniae'.
} 
Kathleen Hughes also suggested that a northern British text (that is, by and about the Britishspeaking peoples of what are now northern England and southern Scotland) was included in 'The Chronicle of Ireland' and Annales Cambriae. It is true that up to the mid-seventh century there are some entries concerning battles between northern Britons, Northumbrians, and Mercians which could derive from such a source, but after 660 the record for the northern Britons is less substantial. ${ }^{201}$ It consists mainly of obits of the British kings of Dumbarton Rock (Ail Cluaithe in Old Gaelic) and battles against Dál Riata or Picts. ${ }^{202}$ Most of the information given in the battleentries concerns protagonists from Dál Riata or Pictland; when the Britons are defeated, their dead are not mentioned. These entries were clearly not written from a British viewpoint. If there were a northern British source, one might expect that events not involving Dál Riata or the Picts would also be recorded, but this is not the case. The only entry about the northern Britons giving any detail is the notice of the burning of Dumbarton in AU 780.1. This is stated to have occurred on the kalends of January, but that this was the first day of the year may have made the event more memorable; so a written source should not be inferred from it. The date could alternatively be a scribal error, resulting from the copying twice of Kl. Ianair, which begins the annal. ${ }^{203}$ Most of the

\footnotetext{
${ }^{201}$ This reduction could be partially the result of the final conquest of British areas by the Northumbrians by the late seventh century. Dumville's argument (Grabowski and Dumville, Chronicles, 207-26) that Annales Cambriae relied on a Clonmacnoise-group text for many entries also weakens Hughes's theory. See Evans, 'The Irish Chronicles', 1720 , for the text of the items relating to these peoples from 600 to 700 , and $27-8$, for analysis of the eighth-century items relating to northern Britain.

${ }^{202}$ Obituary entries about the northern Britons are: possibly AU 663.4 (AT [663].3, CS [663].3), the obit of Tuathal son of Morgand; the obit of Domnall mac Auin, king of Dumbarton, in AU 694.6 (AT [694].2, ARC §154.2); possibly a filius Maithgernain in AU 713.4 (AT [713].4); Bile mac Eilphin, king of Dumbarton, in AU 722.3 (AT [722].3); possibly Tolarggan Maphan in AU 725.3; and Taudar mac Bile, king of Dumbarton, in AT [752].2. Battle-entries are: AT 678.5, which may have combined a British battle with a conflict involving Cenél Loairn found in AU 678.3; AU 711.5 (AT [711].5) and AU 717.5 (AT [717].4, CS [717].3, ARC §*170.5), both against Dál Riata; and AU 750.4 (AT [750].5) against the Picts. The battle of Calathros (AU 678.7, AT [678].8, CS [678].3, AClon 674.6) may have involved the Britons, as Strathcarron (AU 686.2, AT [686].6, CS [682].1, AClon 681.1) did, but they are both duplicates of events from earlier in the seventh century (the leader of Dál Riata in these battles, Domnall Brecc, died at Strathcarron in AU 642.1, AT kl 144 [642].2, CS [642].1). The defeat of Dál Riata in Ualle Limnae (AU 704.1, AT [704].2, CS [704].1) may have been caused by the Britons of Dumbarton, if this location was around Loch Lomond. The only other entry about the northern Britons is the notice of the burning of Dumbarton in AU 780.1.

${ }^{203}$ This possibility was suggested to me by David Dumville.
} 
northern British entries before 740 are found in groups of entries describing events concerning Dál Riata, Pictland, and Northumbria, which makes it likely that they came from the same source, 'The Chronicle of Iona'. After 740 the evidence is much less substantial; so other routes of transmission, for example via Kingarth on the Isle of Bute, should not be ruled out. ${ }^{204}$

\section{The English and 'The Chronicle of Iona'}

There is a greater level of interest in the English, especially in Northumbria, which is likely to be explained by connections with Iona. ${ }^{205}$ As well as kings of the Northumbrians and Mercians, both Theodore of Tarsus, archbishop of Canterbury, and a daughter of Oswiu of Northumbria, in the monastery of St Hild, are obituarised..$^{206}$ Not only are three battles with the Picts - in 685, 698, and 711 - mentioned, but battles among the English themselves are noticed in 679 and $692 .{ }^{207}$ As well as this, there are entries about a cattle-plague in Saxonia ('the land of the English') and the capturing of Ceolwulf son of Cuthwine. ${ }^{208}$ These all demonstrate quite a high degree of interest in English, especially Northumbrian, affairs.

The raid by the Northumbrians on Brega in 684 and the subsequent return of captives from this raid in 686 would have been relevant to an Irish audience, but that Adomnán, abbot of Iona, was responsible for the prisoners' return (according the Irish chronicle entry) hints at an Iona

\footnotetext{
${ }^{204}$ Obits concerning Kingarth are found at AU 660.1 (AT [660].3, CS [660].3 AFM 659.1), possibly AU 675.3 (AT [675].3, ARC §129.4, AFM 673.2), AU 689.1 (AT [689].2, CS [689].2, ARC §150.1, AFM 688.4), possibly AU 711.6, AU 737.1 (AT [737].1, AFM 732.2), AU 776.6 (AFM 771.9), and AU 790.1 (AFM 785.2). Anderson, Kings, 15-16, suggested that the entries about the kings of Dumbarton and Kingarth need not have been transmitted via Iona.

${ }^{205}$ See Bannerman, Studies, 21-4, and Evans, 'The Irish Chronicles', for discussion and lists of these entries. Duncan, 'Bede', 14-19, argued that Ionan annals (via the priest Ecgberht) were sources for Bede's descriptions of battles between the Picts and English in 685, 698, and 711, a view rejected by Evans ('The Irish Chronicles', 24-6).

${ }^{206}$ AU 691.2, AT [691].2, CS [691].2, AClon 675.4, AFM 686.2, ARC §*152.2; AU 713.3, AT [713].3, ARC §*168.2. ${ }^{207}$ AU 680.4, AT [680].4, CS [680].4; AU 686, AT [686].4, AClon 675.4, FAI §96; AU 693, CS [693].4, AClon 688.3; AU 698.2, AT [698].2, AClon 693.1; AU 711.3, AT [711].3.

${ }^{208}$ AU 699.1, AT [699].2 AClon 695.2; AU 731.3, AT [731].3.
} 
provenance for these entries. ${ }^{209}$ The use of the present passive constringitur for the capture of Ceolwulf in 731, the Latin Saxonia in the cattle-plague entry for 699, and apud, iacuit, and campum in the battle against the Picts in 711, are all typical of 'The Chronicle of Iona' ${ }^{210}$ There is no reason why the inclusion of these items should be attributed to the Anglo-Saxon monk Ecgberht; their vocabulary reflects that of 'The Iona Chronicle', and the interest continued after his death in 729 , as the item included in the annal for 731 on the death of Ceolwulf indicates. ${ }^{211}$

In the seventh century, however, the evidence is less clear. Contra, used to describe a defeat of Æthelred, son of Penda, king of Mercia, is found elsewhere in earlier entries on wars between the Britons and English before 660 and Irish entries from 679 to 709, but not in entries on Dál Riata, Picts, or northern Britons. ${ }^{212}$ The use of a personal name after bellum in battle items instead of a place-name is common in seventh-century items for the northern Britons and English, but is rare elsewhere. $^{213}$ The appearance of this feature occasionally for Gaelic battles in the late seventh century is later than these cases, perhaps indicating the influence of the items on the northern Britons and English on chronicling practice at Iona. It is likely that 'The Iona Chronicle' had access to a source produced in territory which was initially British-speaking but by the end of the seventh century was in the land of the English Northumbrians. ${ }^{214}$ There is uncertainty, however, about

\footnotetext{
${ }^{209}$ AU 685.2, AT [685].2, CS [685].2, AClon 680.2, ARC §*147.1, FAI §90; AU 687.5, AT [687].6 (and AT [689].8), CS [687].5, AClon 682.1, AFM 684.4, ARC $\$ 148.4$ and $\S * 150.2$.

${ }^{210}$ AU 699.1, AT [699].2; AU 711.3, AT [711].3; AU 731.3, AT [731].3. For the stylistic similarities, see pp. \$\$$\$ \$, \$ \$, \$ \$-\$(13-16,19-20)$, above.

${ }^{211}$ Evans, 'The Irish Chronicles', 26-7. See ibid., 20-6, for arguments against a textual connection between 'The Iona Chronicle' and English sources such as Bede's 'Ecclesiastical History of the English People' and 'The Anglo-Saxon Chronicle'.

${ }^{212}$ Ibid., 36. CS [693].3 (Cath contra filium Panteae), AU 693.7 (lacking filium). Contra occurs in Irish chronicles in entries about the Britons and English in AT kl 138 [635].3, AT kl 142 [639].4, AU 642.4, AU 693.7 (CS [693].3) and in Irish events in AU 679.3 (AT [679].3, CS [679].2), AU 682.2 (AT [682].3, CS [682].2), AU 709.2, AU 794.6.

${ }^{213}$ Ibid., 36-7.

${ }^{214}$ Evans, 'The Irish Chronicles', 35, 37-9.
} 
whether this was a single text or the result of repeated written notices transmitting news to Iona, perhaps via Lindisfarne (at least up to 664). ${ }^{215}$

In sum, the English items can be explained by 'The Iona Chronicle', and also the wider contacts of the Iona community, which enabled it to get access to brief written accounts of further events among the Britons and the English in the seventh century. The central role of Iona in the transmission of these records is demonstrated by the relative dearth of notices about the English after about 740, at the same time as events in northern Britain as a whole decline substantially. ${ }^{216}$

\section{Conclusions}

The evidence I have presented indicates that most of the entries for events in northern Britain from 660 to 740 came from a 'Chronicle of Iona'; not only the entries shared by 'The Annals of Ulster' and the Clonmacnoise-group, but also entries present in 'The Annals of Ulster' alone, and most of the entries unique to the Clonmacnoise-group. There is little to suggest that other sources, such as chronicles from Applecross and east of Druim Alban, provided entries independent of 'The Chronicle of Iona' before 740; it is more likely that detailed information from these areas was recorded in 'The Chronicle of Iona'; other regions may have contained 'centres of recording', making written notices of events, but Iona was a 'centre of chronicling'. Other centres of recording may have kept chronicles, but any information they may have provided was generally rewritten by chroniclers in Iona when entered into their own annals, and the surviving form of notices predominantly reflected their casting of events.

\footnotetext{
${ }^{215}$ Ibid., 39. Given that there is no evidence that these items end by 700 and that their influence on the form of Gaelic battle items is also apparent by 700, Ecgberht, who was active later at Iona, is unlikely to have been responsible for their inclusion.

${ }^{216}$ Bannerman (Studies, 21-2) suggested that the lack of interest in English affairs after 740 could be accounted for by the movement of the chronicle from Iona to Ireland.
} 
A stylistic analysis of 'The Chronicle of Iona' confirms Alfred Smyth's proposition that it included entries about Irish events. ${ }^{217}$ Bannerman, however, pointed to significant differences between the records of northern Britain and of Ireland in Irish chronicles: there is less variation in subject matter in Irish entries, scribae, ancoritae, and other titles are given to Irish ecclesiastics but not those in northern Britain. ${ }^{218}$ As well as this, from the early eighth century, entries in Gaelic beginning with the word slogad, 'hosting', or indred, 'foraying, wasting', and which describe expeditions, are found in the Irish record and nowhere else. ${ }^{219}$ There are also obits using the preposition $o$, specifying that someone came from a particular place. These are only found in the Irish record and tend to cluster around places in the southern Midlands of Ireland. ${ }^{220}$ These differences indicate there was at least one other written source for some of the Irish entries, but more work is needed before we can decide whether these entries were transmitted to chroniclers in Ireland via 'The Chronicle of Iona' or combined with the Iona text at a later stage, but still before 912 .

These characteristic 'Irish' features in entries before 740, and the entries for events in northern Britain after 740 that display features of 'The Chronicle of Iona', may challenge the consensus that, around 740, 'The Chronicle of Iona' went to Ireland where it was continued or combined with

\footnotetext{
${ }^{217}$ Smyth, 'The earliest Irish annals', 36-41; but he has overstated the case for Iona as the only source of Irish entries (cf. Kenneth Harrison, 'Epacts in Irish chronicles', Studia Celtica 12/13 (1977-8), 17-32, at 23-6.

${ }^{218}$ Bannerman, Studies, 20, including n. 3.

${ }^{219}$ Slógad occurs before 740 in: AU 707.8, AT [707].4; AU 715.4, AT [715].7; AU 738.9, AT [738].7; AU 756.3. Indred occurs in AU 721.8, AT [721].5, CS [721].1. See Charles-Edwards, The Chronicle of Ireland, I, 23-4, for discussion of these and other items in Gaelic in this section of the annals.

${ }^{220}$ Those events found recorded in both AU and the Clonmacnoise-group are: AU 700.2, AT [700].2, CS [700].2, for the anchorite Áed from Sleaty (Co. Laois); AU 722.3 (AT [722].2), for Máel Corgis from Druim Ing (probably modern Dromin, Co. Louth); AU 725.4 (AT [725].4), for the son of Broccán from Tech Taille (Tehelly, Co. Offaly). AU 730.5 (In Gall o Lilcach: in [Lullymore and Lullybeg, Co. Kildare]) is presumably In Gall Ulcach in AT [729].1. A similar entry for Lilcach, AU 748.9, AT [748].11, is also found after 740. AU have AU 697.11, the obit of the scribe Cassán from Lusca (Lusk, Co. Dublin). There are examples between 660 and 766 where an event is recorded in more than one chronicle but $o$ is found in only one chronicle's entry: AT [728].3 (not in AU 728.3), for Bangor; AT [740].4 (not in AU 740.5), for Clonmacnoise; and AU 751.5 (not in AT [751].7) for Devenish. When these uncertain examples are excluded, the use of $o$ followed by a place-name indicates a distribution centred on the southern Uí Néill and northern Leinster.
} 
Irish sources. ${ }^{221}$ Perhaps a 'Chronicle of Iona' that continued after 740 was included much later than 740, with a decision taken during copying to include fewer entries on events in Britain, which resulted in the change at about 740 . On the other hand, 'The Chronicle of Iona' may have been used by chroniclers in Ireland about 740 or soon after, while the transmission of entries about northern Britain after 740 may have depended on later contacts with chroniclers in Iona and other centres, perhaps including one in southern Pictland. ${ }^{222}$ The latter possibility is more likely to be correct, but a detailed study of the Irish entries in the eighth century is necessary to identify chronicle sources in Ireland and how and when they were compiled. ${ }^{223}$

Although we are not yet certain how 'The Chronicle of Iona' was incorporated into the Irish chronicles, the vocabulary of 'The Chronicle of Iona' nevertheless indicates that we can generally treat it as a contemporary source for the period 660 to 740 . Few of the textual features characteristic of 'The Chronicle of Iona' are found later in 'The Chronicle of Ireland', making it unlikely that many of the entries were substantially rewritten at a later date. The style of the entries also changes over the period in a gradual rather than an abrupt manner. The general impression given by the chronicles is that from about 698 to about 717 the variety of vocabulary, the degree of detail and subject matter, become greater but that the entries are still relatively short. After the annal for 717 , entries for battles and then other entries in the 730s become longer, culminating in the lengthy and

\footnotetext{
${ }^{221}$ For discussions about the end of 'The Chronicle of Iona', see O’Rahilly, Early Irish History and Mythology, 2535; Bannerman, Studies, 25-6; Anderson, Kings, 17-18. Fraser, From Caledonia, 371-3.

${ }^{222}$ See above, pp. $\$ \$ \$$ \$ $\$(29-31)$, for the possibility of sources in northern Britain after 740 other than 'The Chronicle of Iona'.

${ }^{223}$ See Smyth, 'The earliest Irish annals', 21-6, 29-30, for the increase in record for the southern Uí Néill and Leinster around 740, and Hughes, Early Christian Ireland, 123-8, not only on the increase in Irish entries but also on changes in the contents of entries. On a cursory inspection, I find that there does seem to be a change of style after 740; entries after then are briefer, show less variety of language and subject, and introduce new vocabulary, for example fortbe ('devastation'). However, there are also features continuing from before 740, including the use in battle entries of the formula inter/iter $\mathrm{X}$ et/ocus $\mathrm{Y}$ or inter $\mathrm{X}$ inuicem/iter $\mathrm{X}$ féin. Furthermore, the only two entries mentioning sightings of a draco are found before and after 740 in AU 735.6 (AT [735].6, AClon 733.3) and AU 746.2 (AT [746].3, AClon 742.2): this pair probably reflects the interest of a single chronicler. The issue when 'The Chronicle of Iona' was incorporated in a chronicle in Ireland is likely to be complex, being linked to the question of the sources of the Irish entries before 740 .
} 
hyperbolic account of the battle of Áth Senaig in AU 738.4 (AT [738].4). This would seem to indicate a gradually evolving style produced by a number of chroniclers over a long period, rather than a single act of compilation about 740; the latter would probably result in a more uniform style from 660 to $740 . .^{224}$

There are still many issues to settle about the entries for northern Britain and 'The Chronicle of Iona', but we can say with confidence that the extensive record of events in northern Britain in the Irish chronicles from 660 to 740 was largely produced in Iona, as Bannerman proposed, and not in a number of centres. It is also possible that a 'Chronicle of Iona', as well as perhaps a source in southern Pictland, continued to be a source for entries probably written in Ireland from 740 to about 800 , but the evidence is far less conclusive. The degree to which surviving texts of Irish chronicles reflect the original contents of 'The Chronicle of Iona' continues to be uncertain, but what remains provides strong evidence that the Iona community's interests and network of contacts encompassed not just Dál Riata but also Ireland, the Picts, the northern Britons and the Northumbrians in the period from 660 to 740 , and possibly later.

\footnotetext{
${ }^{224}$ Features identified with 'The Chronicle of Iona' do not fall in or out of use at the same time, indicating a degree of stylistic continuity: pergit occurs from 692 to 700, de regno from 672 to 726, expulsus est from 697 to 714, expulsio from 672 to 726, rex without a specified kingship from 713 to 728, present passives from 698 to 738, apud from 695 to 731 , iuxta from 728 to 737 .
} 